"This is the peer reviewed version of the following article: [Journal of clinical nursing, 2020] which has been published in final form at [https://onlinelibrary.wiley.com/doi/10.1111/jocn.15562] purposes in accordance with Wiley Terms and Conditions for Self-Archiving." 
Title: Factors Associated with Return to Work Following Myocardial Infarction: A Systematic Review of Observational Studies

Running title: Return to Work post Myocardial Infarction

\section{Authorship:}

1. Weizhe SUN, BN(Hons) Student, RN1

2. Leila GHOLIZADEH, BSc, MSc, PhD, RN, Lecturer ${ }^{1}$

3. Lin PERRY, MSc, PhD, RN, Professor ${ }^{1}$

4. Kyoungrim KANG, PhD, RN, Assistant Professor ${ }^{2}$

5. Mehrdad HEYDARI, PhD, RN, MACN, Research Assistant ${ }^{1}$

\section{Institution affiliations:}

${ }^{1}$ School of Nursing and Midwifery, Faculty of Health, University of Technology Sydney, 15 Broadway, Ultimo, NSW 2001, Australia.

${ }^{2}$ College of Nursing, Pusan National University, 49 Busandaehak-ro, Mulgeum-eup, Yangsan-si, Gyeongsangnam-do, 50612, Korea.

\section{Corresponding author:}

Weizhe SUN, Faculty of Health, University of Technology Sydney, NSW, Australia; Email: Weizhe.Sun-1@student.uts.edu.au; Telephone: +(61) 478783229.

ORCID: https://orcid.org/0000-0002-5563-7506.

\section{Author contributions:}

WS and LG conceived and designed the study, and contributed to data searching strategy. WS and $\mathrm{KK}$ extracted the data. WS and $\mathrm{MH}$ assessed quality of studies. WS analysed the data and drafted the manuscript. LG, LP, KK and MH made critical revisions to the manuscript for important intellectual content. All authors approved the final version to be submitted.

\section{Acknowledgement:}

This article has been accepted for publication and undergone full peer review but has not been through the copyediting, typesetting, pagination and proofreading process, which may lead to differences between this version and the Version of Record. Please cite this article as doi: 10.1111/JOCN.15562

This article is protected by copyright. All rights reserved 
This paper is a partial requirement for the fulfilment of the Bachelor of Nursing (Honours) programme from University of Technology Sydney, Australia, for the primary author (WS). The primary author (WS) acknowledges the support of the other authors as the supervisory team.

\section{Conflict of interest statement:}

The authors report no conflicts of interest.

\section{Funding:}

This research did not receive any specific grant from funding agencies in the public, commercial or not-for-profit sectors. 
MR. WEIZHE SUN (Orcid ID : 0000-0002-5563-7506)

DR. LEILA GHOLIZADEH (Orcid ID : 0000-0002-6711-3312)

DR. KYOUNGRIM KANG (Orcid ID : 0000-0003-4187-1147)

Article type : Review

\title{
Factors Associated with Return to Work Following Myocardial Infarction: A Systematic Review of Observational Studies
}

\begin{abstract}
Objectives: To identify and critically synthesise literature on return to work of patients following a myocardial infarction, and to identify factors that are associated with this.
\end{abstract}

Background: Understanding when patients return to work after myocardial infarction and what factors are associated with this may be helpful in designing person-centred treatment plans to facilitate patients' rehabilitation and return to work.

Design: A narrative systematic review.

Review methods: Six databases, MEDLINE, CINAHL, Academic Search Complete, EMBASE, SCOPUS, and ProQuest Health and Medicine, and the search engine Google were searched to retrieve peer-reviewed articles published in English from January 2008 to January 2020. In total 22,217 papers were sourced and screened, with 18 papers retained for quality appraisal using the Joanna Briggs Institute Critical Appraisal Tools.

Results: The mean time to return to work varied between 46 and 192 days; about half the participants resumed work by three months. Patients who were male, younger, educated, non-manual workers or owned their own business, and those who evaluated their general and mental health highly, had shorter hospitalisation, fewer comorbidities, complications and mental health issues, were more likely to return to work after myocardial infarction.

This article is protected by copyright. All rights reserved 
Conclusion \& relevance to clinical practice: Findings may help nurses detect patients at increased risk of failure to return to work, and provide appropriate support to facilitate this.

Key words: myocardial infarction; return to work; rehabilitation; modifiable factors; nursing.

This article is protected by copyright. All rights reserved 


\section{What does this paper contribute to the wider global clinical community?}

- Return to work is an important outcome from the perspectives of patients, healthcare systems and the wider community.

- It is known that despite advances in the treatment and management of myocardial infarction over the last decades, return to work rates have not changed much for these patients.

- About half of those affected return to work within three months following their myocardial infarction.

- Individual, healthcare and work-related factors associated with return to work post myocardial infarction were identified.

This article is protected by copyright. All rights reserved 


\section{INTRODUCTION}

In 2016, coronary heart disease (CHD) was the leading cause of death on a global scale with a crude death rate of 126 per 100,000 (World Health Organisation, 2018). Myocardial infarction (MI) is the commonest life-threatening manifestation of CHD. Around every 40 seconds a person in the United States (US) develops a MI, and about $14 \%$ die as a result within the first year post-MI (Benjamin et al., 2019). In Australia, around 7,300 people lost their lives to $\mathrm{MI}$ in 2018: equivalent to an average of 20 deaths each day (Australian Bureau of Statistics, 2019). MI not only results in sudden death, it can also result in disabilities due to the development of functional or cognitive complications, such as arrhythmias, heart failure, depression, and anxiety. These adverse outcomes may negatively affect the healthrelated quality of life (HRQOL) of survivors and their families.

Return to work (RTW) is an important outcome for patients post-MI but associated complications result in some patients being unable to return to their previous employment, or their RTW process may be delayed. This can impose significant financial burden on individuals and the community, considering that approximately $45 \%$ of patients with $\mathrm{Ml}$ are younger than 65 years old (Babić et al., 2015; Mirmohammadi et al., 2014; Laut et al., 2014; Stendardo et al., 2018). Between 2017 and 2018, around 33,000 patients who developed MI in Australia were under the age of 55 (Australian Bureau of Statistics, 2018).

From a health economic perspective, CHD is associated with significant direct and indirect costs. It imposes a significant economic burden on healthcare systems in many countries. In the United Kingdom (UK), for example, CHD cost the healthcare system about $£ 1.8$ billion in 2009 (Townsend et al., 2012); US costs in 2010 were estimated at US\$96 billion (LloydJones et al., 2010), and in Australia in 2008-2009 health expenditure on CHD was estimated at AU\$2.03 billion (Australian Institute of Health and Welfare, 2014). CHD also causes productivity losses for industry. In 2009, production losses due to mortality and morbidity associated with CHD cost the UK over $£ 3$ billion (Townsend et al., 2012). Within the European Union, around 90 million working days a year were estimated to be lost due to CHD (Leal et al., 2006). In Australia, similar productivity losses amounted to about AU $\$ 1.79$ billion in 2004 (Zheng, Ehrlich \& Amin, 2010). MI was estimated to cost over AU $\$ 1.55$ billion in total in Australia between 2017 and 2018 (Saunders, 2018). RTW after MI is clearly important from socio-economic perspectives, and attention to this outcome can help reduce costs for the healthcare industry as well as productivity losses generally.

RTW may be important both for younger patients with a career or work-life still ahead of them and for older people who are not ready to retire from work when they experience MI. From patients' perspectives, inability to RTW or extended sickness absence post-MI can 
produce an economic burden for themselves and their families. People of working age who live with chronic disease may not be considered employable (Şahan et al., 2016). Their income may be drastically reduced, and they may face financial difficulties (Şahan et al., 2016). Conversely, having a job may provide an income that covers patients' living expenses and healthcare costs (where applicable) (Waszkowska \& Szymczak, 2009). In some countries where patients are charged the full, unsubsidised, cost of medications, those who delay or do not RTW after MI may experience adverse health outcomes as they may not afford medications and further treatment.

Ml can negatively affect patients' psychological health. Around $35 \%$ of patients who have acute coronary syndrome present with mild to severe depressive symptoms during hospitalisation (Fukuoka et al., 2009). Patients with MI commonly demonstrate low mood, depression, and fear of future cardiac events (Waszkowska \& Szymczak, 2009). Poor mental health status is one of the main reasons for failure to RTW despite favourable physical conditions (Mirmohammadi et al., 2014). The inability to RTW because of adverse psychological conditions may aggravate the mental health of MI survivors due to feelings of disability and failure; these may be intensified by financial pressures and social isolation. By contrast, people who resume employment after MI have been found to be five times less likely to develop depression and other mental health issues than those who do not continue working (Waszkowska \& Szymczak, 2009). Furthermore, RTW after MI can fulfil individuals' ambitions, enhance self-esteem, positively influence individuals' social position and contribute to high self-assessment (Stendardo et al., 2018; Waszkowska \& Szymczak, 2009).

Cardiac rehabilitation is a significant component of the management of patients who survive an $\mathrm{MI}$, to optimise patients' recovery from the associated pathophysiological and psychosocial complications of Ml. RTW after Ml is frequently considered an important behavioural and functional measure of the effectiveness of cardiac rehabilitation, indicative of patients' recovery and return to normal life (Dreyer et al., 2016; Waszkowska \& Szymczak, 2009).

Nonetheless, despite significant advances in the diagnosis and treatment of $\mathrm{CHD}$ in recent decades, RTW rates have remained unchanged (Mirmohammadi et al., 2014). Understanding when patients RTW after MI and what factors are associated with patients' RTW can be helpful in designing person-centred treatment plans to help patients resume employment, which in turn may improve their mental health status and HRQOL, and benefit healthcare systems. Consequently, this systematic review aimed to determine when patients 
RTW after MI and what factors are associated with the decision to do this. For the purposes of this review, all study definitions of RTW were accepted.

\section{AIMS}

The aims of this review were 1 ) to identify and critically synthesise literature on return to work of patients following a myocardial infarction, and 2) to identify both facilitating and inhibiting factors that are associated with return to work after myocardial infarction.

\section{Methods}

\section{Design}

This was a narrative systematic review, undertaken in line with the Joanna Briggs Institute (JBI) Reviewer's Manual (2017 version) and PRISMA checklist (Moher et al., 2009) (Supplementary file 1). It was registered with the JBI Systematic Review Register and PROSPERO International prospective register of systematic reviews.

\section{Search strategy}

In consultation with a health librarian, a search strategy was designed to identify relevant articles that assessed RTW and factors that are related to this in patients post-MI. Electronic databases searched were MEDLINE, CINAHL, Academic Search Complete, EMBASE, SCOPUS, and ProQuest Health and Medicine, and the Google search engine. Search terms were identified using the $\mathrm{P}$ and $\mathrm{O}$ components of the PICO framework (patient, population or problem, intervention, comparison, and outcome) and MeSH terms, where available. The search terms were: [myocardial infarction* OR myocardial infarct* OR heart attack ${ }^{\star}$ AND [work OR job OR career OR occupation OR employment], searching in the 'title' and 'abstract' only.

\section{Inclusion and exclusion criteria}

Searches sought peer-reviewed studies published between January 2008 and January 2020 to ensure that findings reflected contemporary trends of RTW after MI. If the topic of the study focused on acute coronary syndrome, CHD, or ischemic heart disease, the full text was reviewed and only studies that detailed results about RTW in patients with MI were included. Studies did not need to use the phrase 'RTW' specifically, and use of equivalent terms, such as work resumption, work disability, and sickness absence were also accepted. Both quantitative and qualitative studies were included. There were no limitations on the 
follow-up period or type of $\mathrm{MI}$ - for example, acute / recurrent MI, or ST segment elevation MI / non-ST segment elevation MI. All definitions of RTW applied in studies were accepted.

Articles published in languages other than English were excluded. Only peer-reviewed primary studies were included; publications such as conference abstracts, discussion papers and letters to the editor were excluded. Reference lists of included studies and excluded reviews were checked for relevant papers. Interventional studies, including randomised controlled trials, that involved medical, pharmacological or psychosocial interventions with RTW as a trial outcome were excluded.

\section{Search outcome}

The database searches yielded 22,217 citations of potential relevance, with one additional citation identified searching Google. Duplicated references were removed, leaving 15,133 records for screening. After screening study titles and abstracts for relevance, 160 studies remained. The full text of these papers was reviewed, and review studies, interventional studies, book chapters, conference abstracts, letters to the editor, editorial articles, irrelevant content studies, and non-English language articles were removed. In total, 18 studies conformed to the inclusion criteria (Figure 1).

\section{Quality appraisal}

The quality of included studies was appraised by two authors independently using the JBI Critical Appraisal Tools. A third author compared the appraisal results, and any disagreements were discussed between two authors to achieve a consensus. All 18 studies were retained for the review (Table $1 \& 2$ ).

\section{Data abstraction}

Data abstraction was undertaken independently by two authors, using a pre-developed template which included data on authors, year, country, study design, sample information, factors controlled for, follow-up period, and main findings (Table 3). A third author examined and compared the extracted data, and any differences were resolved by consensus through discussion by two authors.

\section{Data analysis}

Due to significant heterogeneity among the studies, including in participants' characteristics, definitions of RTW, and follow-up periods, meta-analysis was not appropriate and data were analysed descriptively. A convergent integrated approach was used to synthesise data based on the JBI Reviewer's Manual (2017 version). The author group developed and 
agreed on a structure based on the research questions to guide the process of summarising findings descriptively. The findings reported included mean and median timings of RTW and RTW at specified follow-up points. Using content analysis text describing the factors related to RTW were categorised into individual, healthcare and work-related factors. Within the individual category, three sub-categories were identified, of socio-demographic, behavioural, and disease and health-related factors. The frequencies with which studies examined and demonstrated significant associations between specific categories and variables with RTW were counted (Popay et al., 2006).

\section{RESULTS}

The 18 studies included in this review were conducted across four different continents. Twelve originated from Europe, three from Asia, and one study from North America; two studies were carried out multi-nationally, one in the US and Japan, and the other in the US, Spain, and Australia. Only one study used qualitative design (Şahan et al., 2016). The sample size varied from 12 (Şahan et al., 2016) to 22,394 (Smedegaard et al., 2017) participants. In the qualitative study (Şahan et al., 2016), the mean age of participants was younger than 45 years. Two studies recruited only male participants (Şahan et al., 2016; Waszkowska \& Szymczak, 2009), and only one recruited more female than male participants (Dreyer et al., 2016).

Nine studies provided a definition for RTW. In five studies 'work' was considered to refer to full-time or part-time working, or working hours were identified (Attarchi et al., 2012; Fukuoka et al., 2009; Jiang et al., 2018; Laut et al., 2014; Warraich et al., 2018). One study considered participants engaged in paid work (Dreyer et al., 2016). RTW was variously defined: as no social benefit payments received from the Denmark government for four consecutive weeks or at least one week (Laut et al., 2014; Smedegaard et al., 2017), respectively; as "employment status resumption" without further explanation (Stendardo et al., 2018, p. 3). Long-term sickness absence post-Ml was defined as > 90 gross days of sick days taken by the individuals recorded by the Social Insurance Agency of Sweden (Wang et al., 2019).

\section{Mean and median timing of RTW post-MI}

Six studies reported the mean time to RTW post-MI, ranging from 46 days ( $S D=4.12)$ in Iran (Mirmohammadi et al., 2014) to 192 days (SD=17.7) in Spain (Tella et al., 2017). With a follow-up period of 12 months, Stendardo et al. (2018) reported the median time to RTW post-MI of 44 (IQR 33 to 88) days in Italy; Tella et al. (2017), following up participants until 
their first RTW, death or the end of the study, reported median 131 (range 102.1 to 159.9) days in Spain.

\section{RTW at specified follow-up points}

Five studies reported the percentage of participants who RTW within a one month follow-up period, which varied from $21.5 \%$ to $41.7 \%$, with the lowest and highest proportions of patients to RTW in Italy and Denmark, respectively (Attarchi et al., 2012; Laut et al., 2014; Mirmohammadi et al., 2014; Smedegaard et al., 2017; Stendardo et al., 2018). Three studies reported the percentage of patients who RTW within two months of follow-up, at $53.1 \%$, $59.2 \%$ and $60 \%$ of participants (Attarchi et al., 2012; Stendardo et al., 2018; Mirmohammadi et al., 2014), respectively. Two studies reported the percentage of patients who RTW within three months of follow-up, at $46.2 \%$ and $62.5 \%$ of participants (de Jonge et al., 2014; Attarchi et al., 2012), respectively. However, Attarchi et al. (2012) only recruited patients who experienced first time MI, but de Jonge et al. (2014) did not apply any such restriction. Three studies reported the percentage of patients who RTW within six months of follow-up: all were above 70\% (Attarchi et al., 2012; Brink et al., 2008; Fukuoka et al., 2009).

Of eight studies that followed participants for 12 months, seven reported the percentage of patients who RTW exceeding 70\% (de Jonge et al., 2014; Dreyer et al., 2016; Laut et al., 2014; Mirmohammadi et al., 2014; Smedegaard et al., 2017; Stendardo et al., 2018; Warraich et al., 2018) with the remaining study at 55.9\% of patients (Jiang et al., 2018). In three of these eight studies that examined this, the proportion of patients who RTW at one year follow-up reached 90\% (Warraich et al., 2018; Smedegaard et al., 2017; Stendardo et al., 2018).

\section{Factors associated with RTW post-MI}

Studies focused on identifying factors that influenced RTW among MI patients, and these were categorised as individual, healthcare, and work-related factors (Table 4).

\section{Individual factors}

Significant individual factors were presented under the sub-categories of socio-demographic, behavioural, and disease and health-related factors.

\section{Socio-demographic factors}

Consistently, a link was demonstrated between older age and lesser likelihood of RTW. Seven studies that investigated this demonstrated strong associations between age and RTW, all of which linked increasing age with reducing proportions of patients who RTW 
(Attarchi et al., 2012; Brink et al., 2008; de Jonge et al., 2014; Isaaz et al., 2010; Jiang et al., 2018; Laut et al., 2014; Waszkowska \& Szymczak, 2009).

Male gender was strongly associated with greater RTW in seven of the eight studies that examined this (Dreyer et al., 2016; Duijts et al., 2017; Isaaz et al., 2010; Jiang et al., 2018; Şahan et al., 2016; Smedegaard et al., 2017; Warraich et al., 2018). The remaining study reported men as less likely to RTW than women after controlling for confounding factors (Laut et al., 2014). This Scandinavian population study extracted data from the national payment database and recruited relatively more females than many other studies (Laut et al., 2014). Wang et al. (2019) reported women were more likely to experience long-term sickness absence post-MI, which may have contributed to deterred or delayed RTW.

Seven papers examined the relationship between patients' educational level and RTW; six suggested that patients with higher educational qualifications such as a university degree, were more likely to RTW than those less educated (de Jonge et al., 2014; Dreyer et al., 2016; Jiang et al., 2018; Smedegaard et al., 2017; Stendardo et al., 2018; Waszkowska \& Szymczak, 2009). Similarly, lower educational levels were associated with higher rates of long-term sickness absence among patients with MI (Wang et al., 2019).

All three studies that examined social support or isolation found that patients with more social support were more likely to RTW (Dreyer et al., 2016; Şahan et al., 2016; Waszkowska \& Szymczak, 2009). The association between patients' marital status and their RTW was examined in six studies, with two studies finding marriage favoured RTW (Dreyer et al., 2016; Isaaz et al., 2010). In the other four studies, most participants were married which may have led to the non-significant findings between marital status and RTW (Attarchi et al., 2012; Jiang et al., 2018; de Jonge et al., 2014; Laut et al., 2014).

Dreyer et al. (2016) assessed the association between patients' financial strain and RTW in three developed countries of the US, Spain and Australia, and found that financial hardship may be linked with reduced likelihood of RTW. However, the qualitative study from a developing nation, Turkey, showed the converse, with financial stress a factor linked to RTW (Şahan et al., 2016).

\section{Behavioural factors}

Cigarette smoking was significantly linked to poorer RTW in all four studies that considered this, irrespective of whether the patients were current smokers (Attarchi et al., 2012; Dreyer et al., 2016; Warraich et al., 2018), or had a smoking history (Jiang et al., 2018). Sedentary lifestyles were similarly linked with lower work resumption, with walking more steps on a daily basis before MI significantly and positively associated with RTW (Brink et al., 2008).

This article is protected by copyright. All rights reserved 


\section{Disease and health-related factors}

Four studies examined links between myocardial wall damage and patients' RTW. Two found a strong association between the location of MI and RTW, with patients who experienced anterior heart wall damage more likely to RTW (de Jonge et al., 2014; Jiang et al., 2018) compared with damage in other locations, but the other two studies found no such association (Attarchi et al., 2012; Isaaz et al., 2010). Four of six studies that assessed the relationship between left ventricular ejection fraction (LVEF) and RTW found LVEF strongly linked to RTW (Attarchi et al., 2012; de Jonge et al., 2014; Dreyer et al., 2016; Mirmohammadi et al., 2014). In these studies, patients who maintained an LVEF $\geq 40 \%$ were more likely to RTW than those with lower LVEF (Attarchi et al., 2012; de Jonge et al., 2014; Dreyer et al., 2016; Mirmohammadi et al., 2014). One study reported that patients who suffered chest pain and experienced their MI during the daytime had a lower probability of RTW than those who experienced chest pain after seven o'clock at night (Isaaz et al., 2010).

Four of five studies that examined associations between diabetes and RTW found that it was significantly linked with poorer RTW (Attarchi et al., 2012; Dreyer et al., 2016; Smedegaard et al., 2017; Warraich et al., 2018). Four studies that studied associations between proportions of patients with hypertension and patients who RTW post-MI all reported consistent negative associations (Attarchi et al., 2012; Dreyer et al., 2016; Jiang et al., 2018; Warraich et al., 2018). Likewise, participants with hypertension were more likely to have taken sickness absence exceeding 90 days post-Ml (Wang et al., 2019). These results are consistent with those of Dreyer et al. (2016), who reported that patients with fewer rather than greater co-morbid disease risk factors in total were more likely to RTW. However, these findings were contradicted by Isaaz et al. (2010), who reported patients who RTW with more risk factors than those who did not.

All three studies that examined relationships between perceived general health and RTW post-MI found that better self-perceived general health significantly predicted greater likelihood of RTW (Brink et al., 2008; Duijts et al., 2017; Waszkowska \& Szymczak, 2009). Two of these studies also found better self-reported physical health attended by higher probability of RTW (Brink et al., 2008; Waszkowska \& Szymczak, 2009). In the qualitative study by Şahan et al. (2016), seven of 12 participants felt physically weaker after MI, and wanted to leave the labour market permanently.

Depression was negatively related to RTW in all five studies that examined this (de Jonge et al., 2014; Dreyer et al., 2016; Stendardo et al., 2018; Warraich et al., 2018; Waszkowska \& Szymczak, 2009). Three of these studies also examined relationships between anxiety and RTW: two of which found that those who were less anxious were significantly more likely to 
RTW (Stendardo et al., 2018; Waszkowska \& Szymczak, 2009). Wang et al. (2019) found that participants with depression and anxiety reported greater likelihood to delay their RTW. One study examined the association between stress and RTW, and found that participants who perceived less stress were more likely to RTW (Dreyer et al., 2016). In three studies (Duijts et al., 2017; Jiang et al., 2018; Mirmohammadi et al., 2013), the patient's preference to not RTW was a reason for not resuming work after MI.

\section{Healthcare factors}

Four studies evaluated relationships between the duration of hospital stay and RTW, with three studies finding shorter hospital stay post-MI predicted significantly greater likelihood of RTW (Attarchi et al., 2012; Dreyer et al., 2016; Jiang et al., 2018). The relationship between the time taken before calling an ambulance following the experience of chest pain and RTW was reported in only one study (Isaaz et al., 2010), which found that patients with a longer wait time before calling were more likely to RTW. Health care system delay, defined as the time from the first call for emergency service to receiving percutaneous coronary intervention $(\mathrm{PCl})$, was significantly linked with work resumption after $\mathrm{Ml}$, with a higher proportion of patients with delay $\leq 120$ minutes achieving RTW than those with system delay $>120$ minutes (Laut et al., 2014).

Two studies examined the effects of coronary artery bypass graft (CABG) on RTW post-MI. The grafted group reported significantly higher rates of RTW than patients who did not undergo CABG (Attarchi et al., 2012). Participants who received CABG were also significantly more likely to take sick leave $>90$ days than those who received $\mathrm{PCl}$ (Wang et al., 2019). Three other studies compared RTW rates between patients who had and had not undergone $\mathrm{PCl}$, none of which found a significant difference in RTW rates (Jiang et al., 2018; Smedegaard et al., 2017; Warraich et al., 2018). However, one study found a significantly higher proportion of patients RTW if they received PCI with drug-eluting compared to plain stents (Warraich et al., 2018).

Three studies compared the rates of RTW between patients who participated in a CR program and those who did not, two of which failed to show a statistically significant difference between groups (Babić et al., 2015; Isaaz et al., 2010). However, Dreyer et al. (2016) reported that participants who completed CR were significantly more likely to RTW than those who did not. Lastly, the advice that patients received from their doctors about RTW seemed to positively or negatively affect their decision about resuming work (Mirmohammadi et al., 2013; Şahan et al., 2016). 


\section{Work-related factors}

Five studies evaluated the relationship between patients' work types and their RTW status, with results consistently showing that professional and non-manual office workers were significantly more likely to RTW than those working in physically demanding occupations (Attarchi et al., 2012; de Jonge et al., 2014; Dreyer et al., 2016; Isaaz et al., 2010; Stendardo et al., 2018). Similarly, Jiang et al. (2018) found that agricultural workers were most likely to fail to RTW. In addition, self-employed business people took the shortest duration sick leave (Babić et al., 2015; Jiang et al., 2018; Stendardo et al., 2018). Income also appeared to be linked to patients' decisions to RTW; three of four studies that examined this found that salary was a statistically significant factor for RTW. Patients with low paid jobs were less likely to RTW, or more likely to extend their sick leave compared to those with higher salaries (Babić et al., 2015; Jiang et al., 2018; Smedegaard et al., 2017). Additionally, those with high job satisfaction were significantly more likely to RTW than those with low and moderate job satisfaction (Mirmohammadi et al., 2014). In Sahan et al.'s (2016) qualitative study, half of the participants who described their job as stressful, and attributed their MI to the stress of their job, wanted to change their job to prevent recurrent MI. Lastly, job loss was reported as a reason not to RTW after MI (Babić et al., 2015; Dreyer et al., 2016; Mirmohammadi et al., 2014; Warraich et al., 2018).

\section{DISCUSSION}

This review found that the mean RTW time varied between 46 and 192 days, and about half the participants resumed work by three months. One study from Spain reported longer sick leave taken by patients with $\mathrm{Ml}$ than apparently similar patients in studies from other countries (Tella et al., 2017), which warrants investigation.

At one month and one year follow-up, rates of RTW in patients post-MI were highest in the study from Denmark (Smedegaard et al., 2017). This study used data from the national database which comprised all details of weekly benefit payments from the Danish government. As this database was comprised of routinely collected government data, loss to follow-up was less likely, which may partially explain the higher RTW rates. The study definition of RTW (participants who had no benefit payment for one week) may be another reason for the higher RTW rates in this study (Smedegaard et al., 2017). Further, Danish policies for paid sick leave and welfare benefits might also contribute to the higher rates of RTW (Smedegaard et al., 2017).

At one year, the RTW rate was lowest in the study from China. Jiang et al. (2018) proposed that the relatively poor quantity and quality of CR services in China may explain this lower 
rate of RTW. The coercive age-based retirement policy in China, long working hours, and low pay might further discourage RTW.

In summary, exploring factors that are related to RTW, review findings suggest that patients who are male, younger, better educated, non-manual workers or owners of their own business and who highly evaluate their general and mental health, tend to have shorter hospitalisations, fewer comorbidities, complications and mental health issues, and are more likely to RTW after MI.

Review findings indicated that $\mathrm{MI}$ has a greater impact on the working abilities of older patients, with, for example, older patients likely to develop heart failure after MI (Shih et al., 2019). Older patients may also be more financially able to take retirement after experiencing a serious disease (Babić et al., 2015; Şahan et al., 2016). However, further research is needed to clarify if age remains a factor in RTW when other factors are controlled.

Female patients were consistently less likely to RTW compared to their male counterparts. This finding links with previous research in which women demonstrated worse physical and mental health outcomes after MI, perhaps because they were more likely to receive suboptimal care, be older at the time of MI occurrence, and have more comorbidities compared to men (Cenko et al., 2018; Shih et al., 2019). Women might also receive less social support after $\mathrm{MI}$, have greater responsibilities for provision of family care, and undertake more domestic work (Dreyer et al., 2016). Women with a career have been reported as experiencing worse work security, job control, contractual conditions, and self-perceived physical and mental health compared to men (Jiang et al., 2018). Furthermore, women were more likely to attribute the cause of their heart disease to stress (Bennett et al., 2016), and may therefore be reluctant to resume work in order to avoid work-related stressors. Significant gender differences have been seen in recovery goals post-MI. Compared to females, more males had rehabilitation goals of RTW, decreasing job strain, and improving physical function post-MI (Grande \& Romppel, 2011). Additionally, although women are increasingly in employment worldwide, males still predominantly assume responsibility for families' economic well-being, as was evident in the study by Şahan et al. (2016), where men felt pressured to resume work to support themselves and their family financially.

Lower educational levels were associated with worse RTW outcomes post-MI, but future studies are needed to examine if education is independently predictive of RTW. Those with lower educational levels were more likely to work in manual sectors of the labour-market (Attarchi et al., 2012; de Jonge et al., 2014) as such work does not usually require higher education, and this could be a factor underpinning lower RTW after MI. As self-perceived poor physical health is common among those who experienced Ml (Mollon \& Bhattacharjee,

This article is protected by copyright. All rights reserved 
2017), this may also explain the lower rates of RTW in patients with a physically demanding occupation such as farming. Further, highly educated patients may have better understanding of their disease, risk factors, and MI prognosis, while less educated patients may be more likely to attribute their MI to stress (Gholizadeh et al., 2009), which may affect their decision to resume work.

Self-employment was significantly associated with RTW. Patients who were self-employed might not be able to afford an extended period of unemployment (Stendardo et al., 2018), or for those who own businesses, absence from work for long periods (Babić et al., 2015). Selfemployed patients may also have more flexibility in adjusting their workload to their health condition (Stendardo et al., 2018).

Many factors related to RTW may reflect patients' severity of injury from their MI. For example, diabetes, hypertension, and lower LVEF after MI were linked with lower work resumption, but each may be a marker of disease severity. Diabetes in patients with MI has been linked with higher mortality and greater risks of further cardiac events than experienced by those without diabetes (Murcia et al., 2004). Patients who experience MI with subsequent LVEF $<40 \%$ have been reported with worse HRQOL and self-evaluated general health, and higher probability of sudden death and overall mortality than those with LVEF $\geq 40 \%$ (Pettersen et al., 2008; Shiga et al., 2008). These factors may also indicate poorer physical health status after MI, also negatively linked with CHD outcomes such as higher hospital readmission and mortality rates (Wang, Jiang \& Lee, 2016). Similarly, patients who self-rated their general and physical health as poor had lower rates of RTW than those who selfevaluated their physical and general health favourably. Clinical features such as longer hospitalisation may imply greater severity of injury and/or in-hospital complications, also associated with decreased functional capacity, adverse outcomes, and higher mortality in $\mathrm{Ml}$ survivors (Agarwal et al., 2015; Saczynski et al., 2010).

As in this review, smokers were shown to have adverse long-term MI outcomes, such as worse HRQOL, higher mortality, and higher probability of developing heart failure and other adverse cardiac events than those without a smoking history (Buchanan et al., 2015; Haig et al., 2019). Smoking has also been associated with shorter life expectancy and greater numbers of life-years lost after MI (Bucholz et al., 2016).

This review also revealed links between failure to RTW and common mental disorders such as depression and anxiety. Within the wider literature, poorer mental health status predicts worse recovery outcomes, such as an increased risk of recurrent cardiovascular events or death ( $\mathrm{Li}$ et al., 2019). Further research is needed to explore the link between mental health status and CHD outcomes as there remains uncertainty to what extent poorer mental health

This article is protected by copyright. All rights reserved 
drives worse cardiovascular outcomes, or vice versa. The immediate contact with the ambulance service after experiencing chest pain may also reflect patients' psychological status of anxiety in the study of Isaaz et al. (2010), and this mental state may obstruct patients' work resumption. The association between depression and adverse cardiovascular events can be at least partially explained in relation to behavioural factors, particularly physical inactivity (Whooley et al., 2008). Social withdrawal and lack of engagement with physical activity are common in patients with depression (Hallgren et al., 2017), which also affects their RTW and overall cardiovascular outcomes.

Research findings on the relationships between the cumulative effects of risk factors and RTW were complex. Patients with no CVD risk factors were more likely to RTW (Dreyer et al., 2016). However, such patients commonly attributed their Ml solely to their jobs, often after experiencing chest pain while they were working (Isaaz et al., 2010). Where this occurred, Isaaz et al. (2010) postulated that this was why many participants who suffered from chest pain during the day were less likely to RTW. Although more research is needed to investigate how these factors affect patients' RTW post-MI, previous studies have shown correlations between stress, including work stress, and patients' outcomes post-MI. Patients with high stress, in general, had higher risk of experiencing angina and poor general health at one year post-MI, and higher mortality at two years post-MI (Arnold et al., 2012). Patients who perceived high job strain or effort-reward imbalance (considered as a source of job strain) had a higher likelihood of experiencing cardiac death and recurrent $\mathrm{Ml}$ or other $\mathrm{CHD}$ than those with low work stress (Aboa-Éboulé et al. 2011; László et al., 2010).

Another factor that appeared to affect patients' RTW after MI was the recommendation received from doctors, in that patients who were advised by their doctors not to RTW were more likely to quit their job. Conversely, an optimistic view of the patients' health condition from the cardiologist or family doctor was linked with shorter sick leave duration post-MI (Perk, 2007). Many patients fail to RTW because they lack confidence that they can work safely (Haennel \& Tomczak, 2009). The degree to which doctors are trusted may influence patients' decisions whether to take their doctors' advice (Şahan et al., 2016). National and local welfare policies, or the lack of these, may also affect patients' response to their doctors in relation to RTW. This can be contrasted in the studies from Turkey, where patients reported needing to RTW for financial reasons (Şahan et al., 2016), and the Scandinavian studies where people who did not RTW received government benefits (Smedegaard et al., 2017; Wang et al., 2019).

This article is protected by copyright. All rights reserved 


\section{Future research}

Included studies make it clear that further research on RTW is required. Studies are needed to better explore the relationships between gender and RTW post-MI, adjusting the gender imbalance identified in current studies. Larger sample sizes and more sophisticated analyses are required for future studies to adequately reflect the predictive power of variables for RTW. Further, more comprehensive investigation and reportage is required of factors such as smoking, exercise, self-evaluated physical and general health and other CVD risk factors not widely reported by current studies. Finally, a consensus definition could be established of RTW, and alternative methods should be explored, such as government records including welfare department data, to demonstrate patients' RTW status.

\section{Review limitations}

This review has a number of limitations. Firstly, observational studies cannot establish cause and effect relationships between factors and RTW, and only associations can be demonstrated. Exclusion of interventional studies and inclusion of articles only written in English may have meant relevant data were missed. Included studies did not always measure the effects of all potential factors for RTW, and studies did not always fully explain their methods, including details of treatments received by non-CABG and non-PCl comparative groups. The use of self-reported measures could affect the accuracy of data. Gender distribution was not balanced in most studies, with considerably higher proportions of male participants. Some studies did not justify their sample size, and small sample sizes in some studies may have affected the detection of statistically significant differences between groups. Due to heterogeneity among included studies, meta-analysis was not possible.

\section{CONCluSion AND RELEVANCE TO Clinical PRACTICE}

This review reported the proportions of patients who RTW within different timeframes after MI. Findings can be used by healthcare providers as a guide when considering appropriate RTW time for their patients post-MI. They can also be used as a benchmark in development and review of rehabilitation services.

This review examined patients' work status post-MI, and identified factors that were associated with patients' RTW from the individual, healthcare, and work-related aspects. The results of the review may help healthcare professionals including nurses to detect early, while they are still hospitalised, if their patients display characteristics that tend to deter or delay RTW. They may then provide or refer patients to appropriate healthcare services to facilitate RTW, focusing on modifiable factors that meet patients' individual needs. This 
review provides new information about RTW post-MI which can inform nurses' and healthcare providers' preparation of such patients for discharge and their educatation of these patients about factors related to RTW post-MI. Findings can inform development of evidence-based clinical guidelines to assist healthcare policy-makers and providers to minimise the effects of modifiable factors negatively linked with RTW and to support RTW for patients recovering from $\mathrm{MI}$. 


\section{REFERENCE LIST}

Aboa-Éboulé, C., Brisson, C., Maunsell, E., Bourbonnais, R., Vézina, M., Milot, A., \& Dagenais, G. R. (2011). Effort-reward imbalance at work and recurrent coronary heart disease events: a 4-year prospective study of post-myocardial infarction patients. Psychosomatic Medicine, 73(6), 436-447. https://doi.org/10.1097/PSY.0b013e318222b2d8

Agarwal, S., Parashar, A., Garg, A., Ellis, S. G., Tuzcu, E. M., \& Kapadia, S. R. (2015). Length of stay and long-term mortality following ST elevation myocardial infarction. Catheterization and Cardiovascular Interventions, 86(S1), S1-S7. https://doi.org/10.1002/ccd.26071

Arnold, S. V., Smolderen, K. G., Buchanan, D. M., Li, Y., \& Spertus, J. A. (2012). Perceived stress in myocardial infarction: long-term mortality and health status outcomes. Journal of the American College of Cardiology, 60(18), 1756-1763. https://doi.org/10.1016/j.jacc.2012.06.044

Attarchi, M., Rigi, A. A., Mirzamohammadi, E., \& Mohammadi, S. (2012). Assessment of the main factors influencing return to work following myocardial infarction: a longitudinal study. International Journal of Collaborative Research on Internal Medicine \& Public Health, 4(6), 1305-1314.

Australian Bureau of Statistics (2018, December 12). 4364.0.55.001 - National health survey: first results, 2017-18. Australian Bureau of Statistics. https://www.abs.gov.au/AUSSTATS/abs@.nsf/DetailsPage/4364.0.55.001201718?OpenDocument

Australian Bureau of Statistics (2019, September 25). 3303.0 - Causes of death, Australia, 2018. Australian Bureau of Statistics. https://www.abs.gov.au/AUSSTATS/abs@.nsf/Lookup/3303.0Main+Features12018 ?OpenDocument

Australian Institute of Health and Welfare (2014). Health-care expenditure on cardiovascular diseases 2008-09. Australian Institute of Health and Welfare.

Babić, Z., Pavlov, M., Oštrić, M., Milošević, M., Duraković, M. M., \& Pintarić, H. (2015). Reinitiating professional working activity after myocardial infarction in primary percutaneous coronary intervention networks era. International Journal of 
Occupational Medicine and Environmental Health, 28(6), 999-1010. https://doi.org/10.13075/ijomeh.1896.00478

Benjamin, E.J., Muntner, P., Alonso, A., Bittencourt, M.S., Callaway, C.W., Carson, A.P., Chamberlain, A.M., Chang, A.R., Cheng, S., Das, S.R., Delling, F.N., Djousse, L., Elkind, M.S.V., Ferguson, J.F., Fornage, M., Jordan, L.C., Khan, S.S., Kissela, B.M., Knutson, K.L., ... Virani, S.S. (2019). Heart disease and stroke statistics-2019 update: a report from the American Heart Association. Circulation, 139(10), e56e528. https://doi.org/10.1161/CIR.0000000000000659

Bennett, K. K., Clark, J. M., Harry, K., \& Howarter, A. D. (2016). Causal attributions following a cardiac event: Short-and long-term differences in health appraisals and outcomes. Health Psychology Open, 3(1), https://doi.org/10.1177/2055102916632669

Brink, E., Brändström, Y., Cliffordsson, C., Herlitz, J., \& Karlson, B. W. (2008). Illness consequences after myocardial infarction: problems with physical functioning and return to work. Journal of Advanced Nursing, 64(6), 587-594. https://doi.org/10.1111/j.1365-2648.2008.04820.x

Buchanan, D. M., Arnold, S. V., Gosch, K. L., Jones, P. G., Longmore, L. S., Spertus, J. A., \& Cresci, S. (2015). Association of smoking status with angina and health-related quality of life after acute myocardial infarction. Circulation: Cardiovascular Quality and Outcomes, 8(5), 493-500. https://doi.org/10.1161/CIRCOUTCOMES.114.001545

Bucholz, E. M., Beckman, A. L., Kiefe, C. I., \& Krumholz, H. M. (2016). Smoking status and life expectancy after acute myocardial infarction in the elderly. Heart, 102(2), 133139. https://doi.org/10.1136/heartjnl-2015-308263

Cenko, E., Yoon, J., Kedev, S., Stankovic, G., Vasiljevic, Z., Krljanac, G., Kalpak, O., Ricci, B., Miličić, D., Manfrini, O., van der Schaar, M., Badimon, L. \& Bugiardini, R. (2018). Sex differences in outcomes after STEMI: effect modification by treatment strategy and age. JAMA Internal Medicine, 178(5), 632-639. https://doi.org/10.1001/jamainternmed.2018.0514

de Jonge, P., Zuidersma, M., \& Bültmann, U. (2014). The presence of a depressive episode predicts lower return to work rate after myocardial infarction. General Hospital Psychiatry, 36(4), 363-367. https://doi.org/10.1016/j.genhosppsych.2014.03.006 
Dreyer, R.P., Xu, X., Zhang, W., Du, X., Strait, K.M., Bierlein, M., Bucholz, E.M., Geda, M., Fox, J., D'Onofrio, G., Lichtman, J.H., Bueno, H., Spertus, J.A. \& Krumholz, H.M. (2016). Return to work after acute myocardial infarction: comparison between young women and men. Circulation: Cardiovascular Quality and Outcomes, 9(2), S45-S52. https://doi.org/10.1161/CIRCOUTCOMES.115.002611

Duijts, S. F., Van Der Beek, A. J., Bleiker, E. M., Smith, L., \& Wardle, J. (2017). Cancer and heart attack survivors' expectations of employment status: results from the English Longitudinal Study of Ageing. BMC Public Health, 17(640), 1-10. https://doi.org/10.1186/s12889-017-4659-z

Fukuoka, Y., Dracup, K., Takeshima, M., Ishii, N., Makaya, M., Groah, L., \& Kyriakidis, E. (2009). Effect of job strain and depressive symptoms upon returning to work after acute coronary syndrome. Social Science \& Medicine, 68(10), 1875-1881. https://doi.org/10.1016/j.socscimed.2009.02.030

Gholizadeh, L., Salamonson, Y., Worrall-Carter, L., DiGiacomo, M. and Davidson, P.M., 2009. Awareness and causal attributions of risk factors for heart disease among immigrant women living in Australia. Journal of Women's Health, 18(9), pp.13851393. https://doi.org/10.1089/jwh.2008.0956

Grande, G., \& Romppel, M. (2011). Gender differences in recovery goals in patients after acute myocardial infarction. Journal of Cardiopulmonary Rehabilitation and Prevention, 31(3), 164-172. https://doi.org/10.1097/HCR.0b013e31820333c8

Haennel, R.G. \& Tomczak, C.R. (2009). Exercise rehabilitation and return to work following a cardiac event. In S. Kumar (Ed.), Ergonomics for rehabilitation professionals. Taylor \& Francis Group.

Haig, C., Carrick, D., Carberry, J., Mangion, K., Maznyczka, A., Wetherall, K., McEntegart, M., Petrie, M.C., Eteiba, H., Lindsay, M. \& Hood, S. (2019). Current smoking and prognosis after acute ST-segment elevation myocardial infarction: new pathophysiological insights. JACC: Cardiovascular Imaging, 12(6), 993-1003. https://doi.org/10.1016/j.jcmg.2018.05.022

Hallgren, M., Stubbs, B., Vancampfort, D., Lundin, A., Jääkallio, P., \& Forsell, Y. (2017). Treatment guidelines for depression: greater emphasis on physical activity is needed. European Psychiatry, 40, 1-3. https://doi.org/10.1016/j.eurpsy.2016.08.011 
Isaaz, K., Coudrot, M., Sabry, M.H., Cerisier, A., Lamaud, M., Robin, C., Richard, L., da Costa, A., Khamis, H., Abd-Alaziz, A. \& Gerenton, C. (2010). Return to work after acute ST-segment elevation myocardial infarction in the modern era of reperfusion by direct percutaneous coronary intervention. Archives of Cardiovascular Diseases, 103(5), 310-316. https://doi.org/10.1016/j.acvd.2010.04.007

Jiang, Z., Dreyer, R.P., Spertus, J.A., Masoudi, F.A., Li, J., Zheng, X., Li, X., Wu, C., Bai, X., Hu, S., Wang, Y., Krumholz, H.M. \& Chen, H. (2018). Factors associated with return to work after acute myocardial infarction in China. JAMA Network Open, 1(7), e184831. https://doi.org/10.1001/jamanetworkopen.2018.4831

Joanna Briggs Institute (2017). The Joanna Briggs Institute critical appraisal tools for use in JBI systematic reviews. Joanna Briggs Institute.

László, K.D., Ahnve, S., Hallqvist, J., Ahlbom, A. \& Janszky, I. (2010). Job strain predicts recurrent events after a first acute myocardial infarction: the Stockholm Heart Epidemiology Program. Journal of Internal Medicine, 267(6), 599-611. https://doi.org/10.1111/j.1365-2796.2009.02196.x

Laut, K.G., Hjort, J., Engstrøm, T., Jensen, L.O., Hansen, H.T., Jensen, J.S., Pedersen, F., Jørgensen, E., Holmvang, L., Pedersen, A.B., Christensen, E.F., Lippert, F., LangJensen, T., Jans, H., Hansen, P.A., Trautner, S., Kristensen, S.D., Lassen, J.F., Lash, T.L., ... Terkelsen, C.J. (2014). Impact of health care system delay in patients with ST-elevation myocardial infarction on return to labor market and work retirement. The American Journal of Cardiology, 114(12), 1810-1816. https://doi.org/10.1016/j.amjcard.2014.09.018

Leal, J., Luengo-Fernández, R., Gray, A., Petersen, S., \& Rayner, M. (2006). Economic burden of cardiovascular diseases in the enlarged European Union. European Heart Journal, 27(13), 1610-1619. https://doi.org/10.1093/eurheartj/ehi733

Li, H., Qian, F., Hou, C., Li, X., Gao, Q., Luo, Y., Tao, L., Yang, X., Wang, W., Zheng, D. \& Guo, X. (2019). Longitudinal changes in depressive symptoms and risks of cardiovascular disease and all-cause mortality: a nationwide population-based cohort study. The Journals of Gerontology: Series A. https://doi.org/10.1093/gerona/glz228

Lloyd-Jones, D., Adams, R.J., Brown, T.M., Carnethon, M., Dai, S., de Simone, G., Ferguson, T.B., Ford, E., Furie, K., Gillespie, C., Go, A., Greenlund, K., Haase, N., Hailpern, S., Ho, M., Howard, V., Kissela, B., Kittner, S., ... Wylie-Rosett, J. (2010). 
Heart disease and stroke statistics-2010 update: a report from the American Heart Association, Circulation, 121(7), e46-e215.

https://doi.org/10.1161/CIRCULATIONAHA.109.192667

Mirmohammadi, S.J., Sadr-Bafghi, S.M., Mehrparvar, A.H., Gharavi, M., Davari, M.H., Bahaloo, M., Mostaghaci, M. \& Sadr-Bafghi, S.A. (2014). Evaluation of the return to work and its duration after myocardial infarction. ARYA Atherosclerosis, 10(3), 137140.

Moher D., Liberati A., Tetzlaff J., Altman. D.G. \& the PRISMA Group (2009). Preferred reporting items for systematic reviews and meta-analyses: the PRISMA statement. PLoS Medicine, 6(7): e1000097. https://doi.org/10.1371/journal.pmed.1000097

Mollon, L. \& Bhattacharjee, S. (2017). Health related quality of life among myocardial infarction survivors in the United States: a propensity score matched analysis. Health \& Quality of Life Outcomes, 15(235), 1-10. https://doi.org/10.1186/s12955-017-08093

Murcia, A.M., Hennekens, C.H., Lamas, G.A., Jiménez-Navarro, M., Rouleau, J.L., Flaker, G.C., Goldman, S., Skali, H., Braunwald, E. \& Pfeffer, M.A. (2004). Impact of diabetes on mortality in patients with myocardial infarction and left ventricular dysfunction. Journal of the American Medical Association Internal Medicine, 164(20), 2273-2279. https://doi.org/10.1001/archinte.164.20.2273

Perk, J. (2007). Returning to work after myocardial infarction. In J. Perk, P. Mathes, H. Gohlke, C. Monpère, I. Hellemans, H. McGee, P. Sellier \& H. Saner (Eds), Cardiovascular prevention and rehabilitation, Springer.

Pettersen, K.I., Kvan, E., Rollag, A., Stavem, K. \& Reikvam, A. (2008). Health-related quality of life after myocardial infarction is associated with level of left ventricular ejection fraction. BMC Cardiovascular Disorders, 8(28), 1-9. https://doi.org/10.1186/14712261-8-28

Popay, J., Roberts, H., Sowden, A., Petticrew, M., Arai, L., Rodgers, M., Britten, N., Roen, K. \& Duffy, S. (2006). Guidance on the conduct of narrative synthesis in systematic reviews: a product from the ESRC methods programme. Lancaster University.

Saczynski, J.S., Lessard, D., Spencer, F.A., Gurwitz, J.H., Gore, J.M., Yarzebski, J. \& Goldberg, R.J. 2010. Declining length of stay for patients hospitalized with AMI:

This article is protected by copyright. All rights reserved 
impact on mortality and readmissions. The American Journal of Medicine, 123(11), 1007-1015. https://doi.org/10.1016/j.amjmed.2010.05.018

Şahan, C., Demiral, Y., Kılıç, B. \& Aslan, Ö. (2016). Changes in employment status after myocardial infarction among men. Balkan Medical Journal, 33(4), 419-425. https://doi.org/10.5152/balkanmedj.2016.150611

Saunders C. (2018). Economic cost of acute coronary syndrome in Australia: the cost to governments. National Heart Foundation of Australia.

Shiga, T., Hagiwara, N., Ogawa, H., Takagi, A., Nagashima, M., Yamauchi, T., Tsurumi, Y., Koyanagi, R. \& Kasanuki, H. (2009). Sudden cardiac death and left ventricular ejection fraction during long-term follow-up after acute myocardial infarction in the primary percutaneous coronary intervention era: results from the HIJAMI-II registry. BMJ Heart, 95(3), 216-220. https://doi.org/10.1136/hrt.2008.145243

Shih, J.Y., Chen, Z.C., Chang, H.Y., Liu, Y.W., Ho, C.H. \& Chang, W.T. (2019). Risks of age and sex on clinical outcomes post myocardial infarction. International Journal of Cardiology Heart \& Vasculature, 23(100350), 1-6. https://doi.org/10.1016/j.ijcha.2019.100350

Smedegaard, L., Numé, A., Charlot, M., Kragholm, K., Gislason, G. \& Hansen, P.R. (2017). Return to work and risk of subsequent detachment from employment after myocardial infarction: insights from Danish nationwide registries. Journal of the American Heart Association, 6(10), 1-12. https://doi.org/10.1161/JAHA.117.006486

Stendardo, M., Bonci, M., Casillo, V., Miglio, R., Giovannini, G., Nardini, M., Campo, G., Fucili, A. \& Boschetto, P. (2018). Predicting return to work after acute myocardial infarction: socio-occupational factors overcome clinical conditions. PLoS One, 13(12), e0208842. https://doi.org/10.1371/journal.pone.0208842

Tella, N. C., Arnaiz, C. S., Gatius, J. R., Torres, O. Y. \& Santiago, L. G. (2017). Assessment of the length of sick leave in patients with ischemic heart disease. $B M C$ Cardiovascular Disorders, 17(32), 1-7. https://doi.org/10.1186/s12872-016-0460-7

Townsend, N., Wickramasinghe, K., Bhatnagar, P., Smolina, K., Nichols, M., Leal, J., Luengo-Fernandez, R. \& Rayner, M. (2012). Coronary heart disease statistics: a compendium of health statistics. British Heart Foundation.

Wang, M., Vaez, M., Dorner, T. E., Rahman, S., Helgesson, M., Ivert, T. \& Mittendorfer-Rutz, E. (2019). Risk factors for subsequent work disability in patients with acute 
myocardial infarction. European Journal of Public Health, 29(3), 531-540.

https://doi.org/10.1093/eurpub/cky279

Wang, W., Jiang, Y. \& Lee, C. H. (2016). Independent predictors of physical health in community-dwelling patients with coronary heart disease in Singapore. Health and Quality of Life Outcomes, 14(113), 1-7. https://doi.org/10.1186/s12955-016-0514-7

Warraich, H. J., Kaltenbach, L. A., Fonarow, G. C., Peterson, E. D. \& Wang, T. Y. (2018). Adverse change in employment status after acute myocardial infarction: analysis from the TRANSLATE-ACS study. Circulation: Cardiovascular Quality and Outcomes, 11(6), e004528. https://doi.org/10.1161/CIRCOUTCOMES.117.004528

Waszkowska, M. \& Szymczak, W. (2009). Return to work after myocardial infarction: a retrospective study. International Journal of Occupational Medicine and Environmental Health, 22(4), 373-381. https://doi.org/10.2478/v10001-009-0033-4

Whooley, M. A., de Jonge, P., Vittinghoff, E., Otte, C., Moos, R., Carney, R. M., Ali, S., Dowray, S., Na, B., Feldman, M. D. \& Schiller, N. B. (2008), Depressive symptoms, health behaviors, and risk of cardiovascular events in patients with coronary heart disease. Journal of the American Medical Association, 300(20), 2379-2388. https://doi.org/10.1001/jama.2008.711

World Health Organisation (2018, May 24). The top 10 causes of death. World Health Organisation. https://www.who.int/news-room/fact-sheets/detail/the-top-10-causesof-death

Zheng, H., Ehrlich, F. \& Amin, J. (2010). Productivity loss resulting from coronary heart disease in Australia. Applied Health Economics and Health Policy, 8(3), pp. 179-189. https://doi.org/10.2165/11530520-000000000-00000 
Table 1 Quality appraisal content derived from relevant JBI Critical Appraisal Tools (JBI 2017)

\begin{tabular}{|c|c|c|c|c|}
\hline & Qualitative studies & $\begin{array}{l}\text { Case control } \\
\text { studies }\end{array}$ & $\begin{array}{l}\text { Cross sectional } \\
\text { studies }\end{array}$ & Cohort studies \\
\hline Q 1 & $\begin{array}{c}\text { Congruity between } \\
\text { stated philosophical } \\
\text { perspective \& research } \\
\text { methodology }\end{array}$ & Comparable groups & Clear inclusion criteria & $\begin{array}{l}\text { The two similar } \\
\text { groups / recruited } \\
\text { from the same } \\
\text { population }\end{array}$ \\
\hline Q 2 & $\begin{array}{l}\text { Congruity between } \\
\text { research methodology } \\
\& \text { research question / } \\
\text { objectives }\end{array}$ & $\begin{array}{l}\text { Cases \& controls } \\
\text { appropriately } \\
\text { matched }\end{array}$ & $\begin{array}{c}\text { Detailed subjects \& the } \\
\text { setting }\end{array}$ & $\begin{array}{l}\text { Similar exposure } \\
\text { measurement in } \\
\text { both groups }\end{array}$ \\
\hline Q 3 & $\begin{array}{l}\text { Congruity between } \\
\text { research methodology } \\
\& \text { methods used to } \\
\text { collect data }\end{array}$ & $\begin{array}{l}\text { Same criteria used } \\
\text { for identification of } \\
\text { cases \& control }\end{array}$ & $\begin{array}{c}\text { Valid \& reliable } \\
\text { measurement on the } \\
\text { exposure }\end{array}$ & $\begin{array}{l}\text { Valid \& reliable } \\
\text { exposure } \\
\text { measurements }\end{array}$ \\
\hline Q 4 & $\begin{array}{l}\text { Congruity between } \\
\text { research methodology } \\
\text { \& representation \& } \\
\text { analysis of data }\end{array}$ & $\begin{array}{l}\text { Valid \& reliable } \\
\text { exposure } \\
\text { measurements }\end{array}$ & $\begin{array}{c}\text { Objective \& standard } \\
\text { criteria for } \\
\text { measurements }\end{array}$ & $\begin{array}{c}\text { Confounding factors } \\
\text { identified }\end{array}$ \\
\hline Q 5 & $\begin{array}{l}\text { Congruity between } \\
\text { research methodology } \\
\& \text { interpretation of } \\
\text { results }\end{array}$ & $\begin{array}{l}\text { Same exposure } \\
\text { measurements for } \\
\text { cases \& controls }\end{array}$ & $\begin{array}{l}\text { Confounding factors } \\
\text { identified }\end{array}$ & $\begin{array}{l}\text { Strategies to deal } \\
\text { with confounders } \\
\text { stated }\end{array}$ \\
\hline Q 6 & $\begin{array}{l}\text { A statement locating } \\
\text { the researcher } \\
\text { culturally / theoretically }\end{array}$ & $\begin{array}{l}\text { Confounding factors } \\
\text { identified }\end{array}$ & $\begin{array}{l}\text { Strategies to deal with } \\
\text { confounders stated }\end{array}$ & $\begin{array}{c}\text { Groups / } \\
\text { participants free of } \\
\text { the outcomes at the } \\
\text { start }\end{array}$ \\
\hline Q 7 & $\begin{array}{c}\text { Influence of researcher } \\
\text { on research / vice- } \\
\text { versa addressed }\end{array}$ & $\begin{array}{l}\text { Strategies to deal } \\
\text { with confounders } \\
\text { stated }\end{array}$ & $\begin{array}{l}\text { Valid \& reliable } \\
\text { outcome } \\
\text { measurements }\end{array}$ & $\begin{array}{l}\text { Valid \& reliable } \\
\text { outcome } \\
\text { measurements }\end{array}$ \\
\hline Q 8 & $\begin{array}{l}\text { Participants \& their } \\
\text { voices adequately } \\
\text { represented }\end{array}$ & $\begin{array}{l}\text { Standard, valid \& } \\
\text { reliable outcome } \\
\text { measurements for } \\
\text { cases \& controls }\end{array}$ & $\begin{array}{c}\text { Appropriate statistical } \\
\text { analysis }\end{array}$ & $\begin{array}{l}\text { Follow-up time } \\
\text { reported \& long } \\
\text { enough }\end{array}$ \\
\hline Q 9 & $\begin{array}{l}\text { Research ethical } \\
\text { according to current } \\
\text { criteria / recent studies } \\
\text { \& approved by an } \\
\text { appropriate body }\end{array}$ & $\begin{array}{l}\text { Long enough } \\
\text { exposure period }\end{array}$ & & $\begin{array}{c}\text { Follow-up } \\
\text { completed \& loss of } \\
\text { follow-up described }\end{array}$ \\
\hline
\end{tabular}

This article is protected by copyright. All rights reserved 


\begin{tabular}{|l|l|l|l|} 
Q 10 & $\begin{array}{c}\text { Conclusions drawn } \\
\text { from the analysis / } \\
\text { interpretation of the } \\
\text { data }\end{array}$ & $\begin{array}{c}\text { Appropriate } \\
\text { statistical analysis }\end{array}$ & $\begin{array}{c}\text { Strategies to } \\
\text { address incomplete } \\
\text { follow-up applied }\end{array}$ \\
\hline Q 11 & $\begin{array}{c}\text { Appropriate } \\
\text { statistical analysis }\end{array}$ \\
\hline
\end{tabular}

Abbreviations: JBI: Joanna Briggs Institute. 
Table 2 Quality appraisal of the included studies

Critical appraisal questions are based on Table 1.

\begin{tabular}{|c|c|c|c|c|c|c|c|c|c|c|c|c|}
\hline \multicolumn{13}{|c|}{ Quality appraisal table for qualitative research } \\
\hline $\begin{array}{l}\text { Authors } \\
\text { (Year) }\end{array}$ & Q1 & Q 2 & Q 3 & Q4 & Q5 & Q6 & Q7 & Q 8 & Q9 & Q 10 & $\begin{array}{c}\text { Overall } \\
\text { appraisal }\end{array}$ & \\
\hline $\begin{array}{l}\text { Şahan et al. } \\
\text { (2016) }\end{array}$ & $\mathrm{N}$ & Y & Y & Y & Y & $\mathrm{N}$ & $\mathrm{N}$ & Y & Y & $\mathrm{Y}$ & INC & \\
\hline \multicolumn{13}{|c|}{ Quality appraisal table for case control studies } \\
\hline $\begin{array}{l}\text { Authors } \\
\text { (Year) }\end{array}$ & Q1 & Q 2 & Q 3 & Q 4 & Q5 & Q6 & Q7 & Q 8 & Q9 & Q 10 & $\begin{array}{c}\text { Overall } \\
\text { appraisal }\end{array}$ & \\
\hline $\begin{array}{l}\text { Waszkowska \& } \\
\text { Szymczak } \\
(2009)\end{array}$ & Y & Y & Y & $\mathrm{N}$ & $\mathrm{N}$ & $\mathrm{N}$ & N & Y & Y & Y & INC & \\
\hline \multicolumn{13}{|c|}{ Quality appraisal table for cross sectional studies } \\
\hline $\begin{array}{l}\text { Authors } \\
\text { (Year) }\end{array}$ & Q1 & Q 2 & Q 3 & Q 4 & Q5 & Q 6 & Q7 & Q8 & $\begin{array}{c}\text { Overall } \\
\text { Appraisal }\end{array}$ & & & \\
\hline $\begin{array}{l}\text { Dreyer et al. } \\
(2016)\end{array}$ & Y & Y & Y & Y & Y & Y & Y & Y & INC & & & \\
\hline \multicolumn{13}{|c|}{ Quality appraisal table for cohort research } \\
\hline $\begin{array}{c}\text { Authors } \\
\text { (Year) }\end{array}$ & Q1 & Q 2 & Q 3 & Q 4 & Q 5 & Q6 & Q7 & Q 8 & Q9 & Q 10 & Q 11 & $\begin{array}{c}\text { Overall } \\
\text { appraisal }\end{array}$ \\
\hline $\begin{array}{l}\text { Attarchi et al. } \\
\text { (2012) }\end{array}$ & Y & Y & Y & Y & Y & Y & Y & Y & $\mathrm{Y}$ & $U$ & Y & INC \\
\hline Babić et al. & $\mathrm{N} / \mathrm{A}$ & $\mathrm{N} / \mathrm{A}$ & $\mathrm{Y}$ & $\mathrm{N}$ & $\mathrm{N}$ & $\bar{Y}$ & $\bar{Y}$ & $\bar{Y}$ & $\mathrm{Y}$ & $\mathrm{U}$ & $\bar{Y}$ & INC \\
\hline
\end{tabular}

This article is protected by copyright. All rights reserved 


\begin{tabular}{|c|c|c|c|c|c|c|c|c|c|c|c|c|}
\hline (2015) & & & & & & & & & & & & \\
\hline $\begin{array}{l}\text { Brink et al. } \\
\text { (2008) }\end{array}$ & $\mathrm{Y}$ & $Y$ & $Y$ & $Y$ & $Y$ & $Y$ & $Y$ & $Y$ & $Y$ & $\mathrm{~N} / \mathrm{A}$ & $Y$ & INC \\
\hline $\begin{array}{l}\text { de Jonge, } \\
\text { Zuidersma \& } \\
\text { Bültmann } \\
\text { (2014) }\end{array}$ & $Y$ & $\mathrm{Y}$ & $Y$ & $Y$ & $Y$ & $Y$ & $Y$ & $Y$ & $Y$ & $\mathrm{~N}$ & $Y$ & INC \\
\hline $\begin{array}{l}\text { Duijts et al. } \\
\text { (2017) }\end{array}$ & $Y$ & $Y$ & $\mathrm{~N}$ & $Y$ & $Y$ & $\mathrm{Y}$ & $Y$ & $Y$ & $Y$ & $\mathrm{~N} / \mathrm{A}$ & $Y$ & INC \\
\hline $\begin{array}{l}\text { Fukuoka et al. } \\
\text { (2009) }\end{array}$ & $\mathrm{Y}$ & $Y$ & $Y$ & $Y$ & $Y$ & $\mathrm{Y}$ & $Y$ & $Y$ & $Y$ & $U$ & $Y$ & INC \\
\hline $\begin{array}{l}\text { Isaaz et al. } \\
(2010)\end{array}$ & $Y$ & $Y$ & $Y$ & $Y$ & $Y$ & $\mathrm{Y}$ & $\mathrm{N}$ & $Y$ & $Y$ & $\mathrm{~N}$ & $Y$ & INC \\
\hline $\begin{array}{l}\text { Jiang et al. } \\
\text { (2018) }\end{array}$ & $Y$ & $\mathrm{Y}$ & $Y$ & $Y$ & $Y$ & $Y$ & $Y$ & $Y$ & $Y$ & $\mathrm{~N}$ & $Y$ & INC \\
\hline $\begin{array}{l}\text { Laut et al. } \\
\text { (2014) }\end{array}$ & $Y$ & $\mathrm{Y}$ & $Y$ & $Y$ & $Y$ & $Y$ & $Y$ & $Y$ & $Y$ & $U$ & $Y$ & INC \\
\hline $\begin{array}{l}\text { Mirmohammadi } \\
\text { et al. (2014) }\end{array}$ & $Y$ & $\mathrm{Y}$ & $Y$ & $\mathrm{~N}$ & $\mathrm{~N}$ & $Y$ & $Y$ & $Y$ & $Y$ & $\mathrm{~N}$ & $Y$ & INC \\
\hline $\begin{array}{l}\text { Smedegaard et } \\
\text { al. (2017) }\end{array}$ & $\mathrm{Y}$ & $Y$ & $Y$ & $Y$ & $Y$ & $\mathrm{Y}$ & $Y$ & $Y$ & $Y$ & $U$ & $Y$ & INC \\
\hline $\begin{array}{l}\text { Stendardo et } \\
\text { al. (2018) }\end{array}$ & $\mathrm{N}$ & $\mathrm{N}$ & $Y$ & $Y$ & $Y$ & $Y$ & $Y$ & $Y$ & $Y$ & $U$ & $Y$ & INC \\
\hline $\begin{array}{l}\text { Tella et al. } \\
\text { (2017) }\end{array}$ & $\mathrm{Y}$ & $Y$ & $Y$ & $Y$ & $Y$ & $\mathrm{Y}$ & $\mathrm{N}$ & $Y$ & $Y$ & $U$ & $Y$ & INC \\
\hline
\end{tabular}

This article is protected by copyright. All rights reserved 


\begin{tabular}{|l|c|c|c|c|c|c|c|c|c|c|c|c|}
$\begin{array}{l}\text { Wang et al. } \\
\text { (2019) }\end{array}$ & $Y$ & $Y$ & $Y$ & $Y$ & $Y$ & $Y$ & $Y$ & $Y$ & $U$ & $U$ & $Y$ & INC \\
\hline $\begin{array}{l}\text { Warraich et al. } \\
\text { (2018) }\end{array}$ & N/A & N/A & $Y$ & $Y$ & $Y$ & $Y$ & $Y$ & $Y$ & $Y$ & $U$ & $Y$ & INC \\
\hline
\end{tabular}

Abbreviations: Q: Question; Y: Yes; N: No; N/A: Not applicable; U: Unclear; INC: Include.

This article is protected by copyright. All rights reserved 
Table 3 Characteristics of included studies

\begin{tabular}{|c|c|c|c|c|c|}
\hline $\begin{array}{c}\text { Authors } \\
\text { (Year), } \\
\text { Countries }\end{array}$ & Study Design & $\begin{array}{l}\text { Sample Information } \\
\text { (Age, Gender, Setting) }\end{array}$ & $\begin{array}{c}\text { Factors } \\
\text { Controlled For }\end{array}$ & $\begin{array}{l}\text { Follow-up } \\
\text { Period }\end{array}$ & Main Results \\
\hline $\begin{array}{l}\text { Attarchi et al. } \\
\text { (2012), Iran }\end{array}$ & $\begin{array}{l}\text { Quantitative, } \\
\text { observational, } \\
\text { longitudinal, } \\
\text { survey }\end{array}$ & $\begin{array}{l}\mathrm{N}=384, \text { Mean age: } 52 \\
\text { years old (SD: N/A), } \\
\text { Males: } 372(97 \%) \text {, } \\
\text { Setting: a general } \\
\text { hospital in Tehran }\end{array}$ & $\begin{array}{l}\text { Age, DM, duration } \\
\text { of hospitalisation, } \\
\text { angina post-MI, } \\
\text { CABG, LVEF }\end{array}$ & $\begin{array}{l}7 \text { months post- } \\
\text { MI }\end{array}$ & 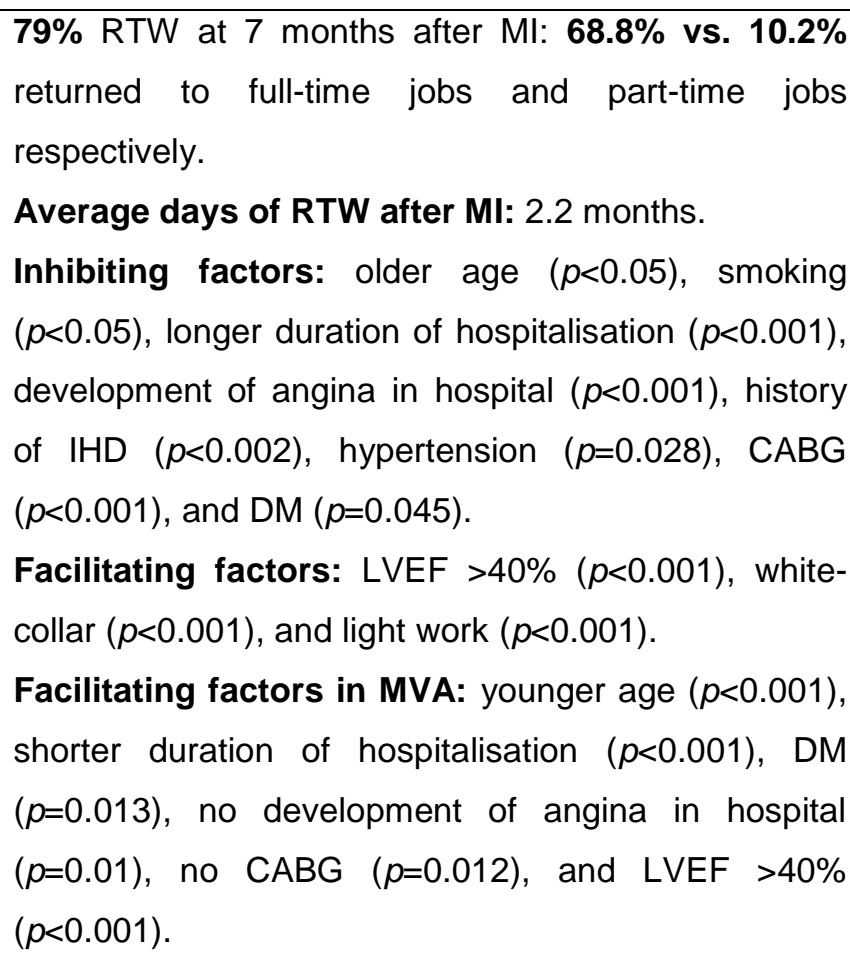 \\
\hline $\begin{array}{l}\text { Babić et al. } \\
\text { (2015), Croatia }\end{array}$ & $\begin{array}{l}\text { Prospective, } \\
\text { single-centre, } \\
\text { open trial } \\
\text { involving the } \\
\text { blinded }\end{array}$ & $\begin{array}{l}\mathrm{N}=145, \text { Mean age: } \\
53.17 \text { years old }(\mathrm{SD}: \\
7.29) \text {, Males: } 128 \\
(88.3 \%) \text {, Setting: Sestre } \\
\text { Milosrdnice University }\end{array}$ & $\begin{array}{l}\text { Age, } \\
\text { lipoproteinemia, } \\
\text { educational level }\end{array}$ & $\begin{array}{l}24 \text { months post } \\
\text { PPCI }\end{array}$ & $\begin{array}{l}\text { The average days of RTW for pts with PPCI after } \\
\text { STEMI: } 125.83 \pm 125.04 \text { days. } \\
35.2 \% \text { took extended sick leave: median } 17.1 \pm 6.2 \text { vs. } \\
3.9 \pm 2.5 \text { days due to cardiac and non-cardiac causes } \\
\text { respectively. }\end{array}$ \\
\hline
\end{tabular}

This article is protected by copyright. All rights reserved 


\begin{tabular}{|c|c|c|c|c|c|}
\hline & $\begin{array}{l}\text { evaluation of } \\
\text { the end points }\end{array}$ & $\begin{array}{l}\text { Hospital Centre at } \\
\text { Zagreb in Croatia }\end{array}$ & & & $\begin{array}{l}\text { Factors affected sick leave duration: salary before } \\
(p=0.007) \text { and after }(p=0.005) \text {, STEMI, and self- } \\
\text { evaluated QoL post STEMI }(p=0.017) \text {. } \\
\text { Factors affecting permanent job leave: age } \\
(p=0.009) \text {. } \\
\text { Facilitating factors: white-collar or self-employed } \\
\text { business ( } p=0.001) \text {. } \\
\text { Inhibiting factors in MVA: older age ( } p<0.001) \text {, } \\
\text { hyperlipoproteinemia ( } p<0.05) \text {, and lower education } \\
(p<0.05) \text {. }\end{array}$ \\
\hline $\begin{array}{l}\text { Brink et al. } \\
\text { (2008), } \\
\text { Sweden }\end{array}$ & $\begin{array}{l}\text { Quantitative, } \\
\text { longitudinal }\end{array}$ & $\begin{array}{l}\mathrm{N}=88, \text { Mean age: } 57 \\
\text { years old (SD: } 7) \text {, } \\
\text { Males: } 65 \text { (74\%), } \\
\text { Setting: a rural hospital } \\
\text { in Sweden }\end{array}$ & $\begin{array}{l}\text { Age, PCS, } \\
\text { footsteps per day }\end{array}$ & $\begin{array}{l}4 \text { and } 6 \text { months } \\
\text { post-Ml }\end{array}$ & $\begin{array}{l}80 \% \text { vs. } 55 \% \text { RTW in pts who were employed before } \\
\text { MI and all pts respectively. } \\
\text { Inhibiting factors: older age ( } p=0.005) \text {, and more } \\
\text { physical health issues (SHCQ) (e.g. pain ( } p=0.005) \text {, } \\
\text { bodily pain ( } p=0.005) \text {, and fatigue }(p=0.011)) \text {. } \\
\text { Facilitating factors: greater physical health (SHCQ) } \\
(p=0.000) \text {. } \\
\text { Facilitating factors in MVA: higher PCS }(p=0.011) \text {, } \\
\text { and more daily footsteps }(p=0.033) \text {. }\end{array}$ \\
\hline $\begin{array}{l}\text { de Jonge, } \\
\text { Zuidersma \& } \\
\text { Bültmann } \\
\text { (2014), } \\
\text { Netherlands }\end{array}$ & $\begin{array}{l}\text { Prospective, } \\
\text { cohort }\end{array}$ & $\begin{array}{l}\mathrm{N}=200, \mathrm{RTW} \text { group }= \\
\text { 133, NRTW group }=40, \\
\text { no data on RTW }=27, \\
\text { Mean age: RTW group: } \\
49.7 \text { years old (SD: } 6.7 \text { ), } \\
\text { NRTW group: } 53.7 \\
\text { years old (SD: } 9.5) \text {, }\end{array}$ & $\begin{array}{l}\text { Age, gender, LVEF, } \\
\text { depression }\end{array}$ & $\begin{array}{l}3 \text { and } 12 \\
\text { months post-Ml }\end{array}$ & $\begin{array}{l}46.2 \% \text { vs. } 76.9 \% \text { RTW at three and } 12 \text { months post- } \\
\text { MI respectively. } \\
\text { Facilitating factors at three months: higher } \\
\text { educational degree }(p<0.01) \text {, white-collar }(p<0.05) \text {, } \\
\text { and light work ( } p<0.01) \text {. } \\
\text { Facilitating factors at } 12 \text { months: younger age } \\
(p<0.01) \text {, LVEF } \geq 40 \%(p<0.01) \text {, higher Killip Class }\end{array}$ \\
\hline
\end{tabular}

This article is protected by copyright. All rights reserved 


\begin{tabular}{|c|c|c|c|c|c|}
\hline & & $\begin{array}{l}\text { Males: RTW group: } 122 \\
\text { (91.7\%), NRTW group: } \\
35 \text { (87.5\%), Setting: } 4 \\
\text { hospitals north } \\
\text { Netherlands }\end{array}$ & & & $\begin{array}{l}(p<0.05) \text {, and anterior } \mathrm{Ml}(p<0.05) \text {. } \\
\text { Depression }(p=0.013) \text { during the first three months } \\
\text { post-MI significantly affected pts to not RTW at } 12 \\
\text { months post-MI. }\end{array}$ \\
\hline $\begin{array}{l}\text { Dreyer et al. } \\
\text { (2016), USA, } \\
\text { Spain \& } \\
\text { Australia }\end{array}$ & $\begin{array}{l}\text { Quantitative, } \\
\text { observational, } \\
\text { longitudinal }\end{array}$ & $\begin{array}{l}\mathrm{N}=1,680, \text { Mean age: } \\
\text { males: } 48 \text { years old } \\
\text { (IQR: } 8.0) \text {, females: } 48 \\
\text { years old (IQR: } 8.0), \\
\text { Males: } 718 \text { (42.7\%), } \\
\text { Setting: } 103 \text { USA, } 24 \\
\text { Spanish, and } 3 \\
\text { Australian hospitals }\end{array}$ & $\begin{array}{l}\text { Age, gender, } \\
\text { ethnicity, marital } \\
\text { status, children, } \\
\text { educational level, } \\
\text { country, insurance, } \\
\text { job changes, } \\
\text { working hours per } \\
\text { week, work type, } \\
\text { depression, stress, } \\
\text { social support, } \\
\text { financial hardship, } \\
\text { physical health, } \\
\text { hypertension, DM, } \\
\text { dyslipidaemia, } \\
\text { smoking, previous } \\
\text { CHD, BMI, STEMI, } \\
\text { LVEF, CR, duration } \\
\text { of hospitalisation }\end{array}$ & $\begin{array}{l}12 \text { months post- } \\
\mathrm{MI}\end{array}$ & $\begin{array}{l}86 \% \text { RTW at } 12 \text {-month follow-up: } 85 \% \text { vs. } 89 \% \text { of } \\
\text { male and female pts respectively }(p=0.02) \text {. } \\
\text { Facilitating factors at } 12 \text { months post-MI: male } \\
\text { gender ( } p=0.02) \text {, being married }(p<0.001) \text {, higher } \\
\text { education ( } p<0.001) \text {, insurance }(p<0.001) \text {, not } \\
\text { changing jobs frequently ( } p=0.025) \text {, working more } \\
\text { hours ( } p=0.044) \text {, white-collar ( } p<0.0010) \text {, fewer risk } \\
\text { factors (no DM ( } p=0.019) \text {, no smoking ( } p=0.001) \text {, } \\
\text { LVEF } \geq 40 \% \text { ( } p=0.024) \text { and CR ( } p=0.007) \text {, less } \\
\text { depression ( } p<0.001) \text { less stress ( } p<0.001) \text {, more } \\
\text { social support ( } p=0.131) \text { and less financial stress } \\
\text { ( } p<0.001) \text {. } \\
\text { Facilitating factors at } 12 \text { months post-MI in MVA: } \\
\text { being married, white-collar, greater physical health } \\
\text { (SF-12), and no history of CAD and hypertension. }\end{array}$ \\
\hline $\begin{array}{l}\text { Duijts et al. } \\
\text { (2017), UK }\end{array}$ & $\begin{array}{l}\text { Population- } \\
\text { based, } \\
\text { prospective, }\end{array}$ & $\begin{array}{l}N=537, \text { Diagnosed as } \\
M I=191, \text { Males: } 157 \\
\text { (82.2\%), Setting: }\end{array}$ & $\begin{array}{l}\text { Gender, } \\
\text { expectation of } \\
\text { being at work after }\end{array}$ & $\begin{array}{l}24 \text { months post- } \\
\text { MI }\end{array}$ & $\begin{array}{l}\text { Inhibiting factors: female gender }(p=0.094) \text {. } \\
\text { Facilitating factors: greater general health (GHQ) } \\
(p=0.042) \text {, and higher expectation of being at work }\end{array}$ \\
\hline
\end{tabular}

This article is protected by copyright. All rights reserved 


\begin{tabular}{|c|c|c|c|c|c|}
\hline & cohort & England & certain age & & $\begin{array}{l}(p=0.074) \text {. } \\
\text { Facilitating in MVA: male gender }(p=0.018) \text {, and } \\
\text { higher expectation of being at work }(p=0.033) \text {. }\end{array}$ \\
\hline $\begin{array}{l}\text { Fukuoka et al. } \\
\text { (2009), USA \& } \\
\text { Japan }\end{array}$ & $\begin{array}{l}\text { Quantitative, } \\
\text { prospective, } \\
\text { longitudinal }\end{array}$ & $\begin{array}{l}\mathrm{N}=212 \text {, Diagnosed as } \\
\text { STEMI = 121, Mean } \\
\text { age: } 53 \text { years old (SD: } \\
\text { 9.3), Males: } 180 \\
(84.5 \%) \text {, Setting: } 3 \\
\text { hospitals in USA, } 5 \text { in } \\
\text { Japan }\end{array}$ & $\begin{array}{l}\text { Age, gender, } \\
\text { educational level, } \\
\text { job strain before } \\
\text { ACS, BDI-II score, } \\
\text { DASI }\end{array}$ & $\begin{array}{l}2 \text { and } 6 \text { months } \\
\text { post hospital } \\
\text { admission }\end{array}$ & 86.8\% RTW post-MI. \\
\hline $\begin{array}{l}\text { Isaaz et al. } \\
(2010) \text {, France }\end{array}$ & $\begin{array}{l}\text { Quantitative, } \\
\text { observational, } \\
\text { longitudinal }\end{array}$ & $\begin{array}{l}\mathrm{N}=200, \text { Mean age: } 48 \\
\text { years old (SD: } 7), \\
\text { Males: } 184(92 \%), \\
\text { Setting: University } \\
\text { Hospital of Saint- } \\
\text { Étienne }\end{array}$ & $\begin{array}{l}\text { Age, gender, chest } \\
\text { pain onset during } \\
\text { day time, blue } \\
\text { collar professions, } \\
\text { time to call } \\
\text { ambulance service, } \\
\text { marital status, } \\
\text { number of risk } \\
\text { factors, multiple } \\
\text { vessel disease, } \\
\text { period of } \\
\text { hospitalisation, CR }\end{array}$ & $\begin{array}{l}\text { Median } 3 \text { and } \\
\text { half years post- } \\
\text { MI }\end{array}$ & 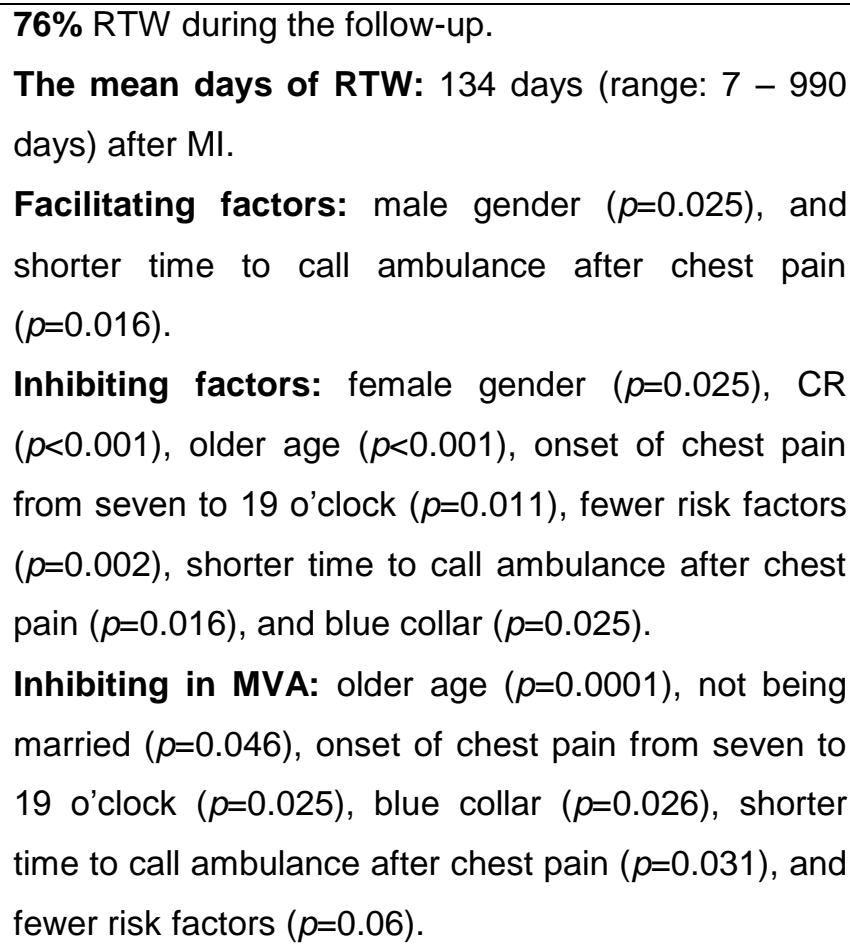 \\
\hline
\end{tabular}

This article is protected by copyright. All rights reserved 


\begin{tabular}{|c|c|c|c|c|c|}
\hline & & & & & $\begin{array}{l}\text { Among pts RTW, factors affected pts' late RTW in } \\
\text { MVA: CR ( } p=0.0011) \text {, blue collar ( } p=0.01) \text {, duration of } \\
\text { hospitalisation ( } p=0.015) \text {, and TIMI flow grade } 3 \\
\text { ( } p=0.022) \text {. } \\
\text { Factors affected pts' RTW within three months } \\
\text { after MI (early return): less anterior STEMI } \\
(p=0.0077) \text {, no CR ( } p=0.001) \text {, LVEF } \geq 40 \% \\
(p=0.0143) \text {, and shorter duration of hospitalisation } \\
(p=0.0164) \text {. }\end{array}$ \\
\hline $\begin{array}{l}\text { Jiang et al. } \\
\text { (2018), China }\end{array}$ & $\begin{array}{l}\text { Quantitative, } \\
\text { prospective, } \\
\text { cohort }\end{array}$ & $\begin{array}{l}\mathrm{N}=1,566, \text { Mean age: } \\
52.2 \text { (SD: } 9.7) \text {, Males: } \\
1,436(91.7 \%) \text {, Setting: } \\
53 \text { hospitals in China }\end{array}$ & $\mathrm{N} / \mathrm{A}$ & $\begin{array}{l}12 \text { months post } \\
\text { discharge }\end{array}$ & $\begin{array}{l}55.9 \% \text { RTW within } 12 \text { months after Ml: } 41.5 \% \text { did not } \\
\text { have the capacity to work, or did not want to go back } \\
\text { to work due to Ml; } 19.0 \% \text { retired directly due to MI. } \\
\text { Inhibiting factors: older age }(p<0.001) \text {, female } \\
\text { gender ( } p<0.001) \text {, farmers }(p<0.001) \text {, hypertension } \\
(p=0.03) \text {, development of stroke ( } p=0.13) \text {, AF } \\
\text { ( } p=0.47) \text {, angina ( } p=0.008) \text {, and infection }(p=0.04) \text { in } \\
\text { hospital, recurrence of angina post-MI ( } p=0.03) \text {, lower } \\
\text { education ( } p<0.001) \text {, lower salary before MI } \\
\text { ( } p<0.001) \text {, longer duration of hospitalisation }(p=0.04) \text {, } \\
\text { smoking, and dyslipidaemia. } \\
\text { Facilitating factors: higher education, T2DM, and } \\
\text { anterior MI }\end{array}$ \\
\hline $\begin{array}{l}\text { Laut et al. } \\
\text { (2014), } \\
\text { Denmark }\end{array}$ & $\begin{array}{l}\text { Quantitative, } \\
\text { population- } \\
\text { based, } \\
\text { historical, }\end{array}$ & $\begin{array}{l}\mathrm{N}=4,061, \mathrm{HCSD} \leq 120 \\
\text { mins group }=2305, \\
\mathrm{HCSD}>120 \text { mins group } \\
=1756, \text { Mean age: }\end{array}$ & $\begin{array}{l}\text { HCSD }>120 \text { mins, } \\
\text { age, gender, } \\
\text { marriage, } \\
\text { comorbidity, }\end{array}$ & $\begin{array}{l}8 \text { years post } \\
\mathrm{PPCl}\end{array}$ & $\begin{array}{l}29 \% \text { vs. } 25 \% \text { RTW in no HCSD and HCSD groups } \\
\text { respectively at one month post PPCI. } \\
96 \% \text { vs. } 94 \% \text { returned full-time jobs in no HCSD and } \\
\text { HCSD groups respectively at one month post PPCl. }\end{array}$ \\
\hline
\end{tabular}

This article is protected by copyright. All rights reserved 


\begin{tabular}{|c|c|c|c|c|c|}
\hline & cohort & $\begin{array}{l}\text { HCSD } \leq 120 \text { mins group: } \\
54 \text { years old (SD: N/A), } \\
\text { HCSD >120 mins group: } \\
55 \text { years old (SD: N/A), } \\
\text { Males: HCSD } \leq 120 \\
\text { mins group: } 1971 \\
\text { (85.5\%), HCSD >120 } \\
\text { mins group: } 1465 \\
\text { (83.4\%), Setting: Danish } \\
\text { National Register on } \\
\text { Public Transfer } \\
\text { Payments }\end{array}$ & smoker, year & & $\begin{array}{l}\mathbf{8 7 \%} \text { vs. } 83 \% \text { RTW in no HCSD and HCSD groups } \\
\text { respectively at one year follow-up. } \\
93 \% \text { vs. } 89 \% \text { RTW in no HCSD and HCSD groups } \\
\text { respectively at four years follow-up. } \\
\text { Mean sick leave length: } 10 \text { weeks vs. } 12 \text { weeks in } \\
\text { no HCSD and HCSD groups respectively. Inhibiting } \\
\text { factors in MVA: male gender ( } p<0.001) \text {, HCSD } \\
(p<0.001) \text {, and older age }(p<0.05) \text {. }\end{array}$ \\
\hline $\begin{array}{l}\text { Mirmohammadi } \\
\text { et al. (2014), } \\
\text { Iran }\end{array}$ & $\begin{array}{l}\text { Quantitative, } \\
\text { observational, } \\
\text { longitudinal }\end{array}$ & $\mathrm{N}=174$ & $\mathrm{~N} / \mathrm{A}$ & $\begin{array}{l}12 \text { months post- } \\
\text { MI }\end{array}$ & $\begin{array}{l}30 \% \text { vs. } 60 \% \text { vs. } 77 \% \text { RTW during } 40 \text { days after MI, } \\
50 \text { days after } \mathrm{Ml} \text {, and at one year after MI } \\
\text { respectively. } \\
\text { Mean days of RTW: } 46 \pm 4.12 \text { days. } \\
\text { Facilitating factors: higher job satisfaction ( } p=0.35 \text { ), } \\
\text { and LVEF } \geq 40 \% \text { ( } p=0.007) \text {. } \\
\text { Inhibiting factors: patients' own decision ( } 45 \%) \text {, Drs' } \\
\text { advice }(22.5 \%) \text {, and retirement }(10 \%) \text {. }\end{array}$ \\
\hline $\begin{array}{l}\text { Şahan et al. } \\
\text { (2016), Turkey }\end{array}$ & Qualitative & $\begin{array}{l}\mathrm{N}=12, \text { Mean age: } 43.9 \\
\text { years old, Males: } 12 \\
(100 \%) \text {, Setting: a } \\
\text { university hospital } \\
\text { coronary care unit }\end{array}$ & $\mathrm{N} / \mathrm{A}$ & $\mathrm{N} / \mathrm{A}$ & $\begin{array}{l}\text { Most pts worked at the same job, but for less hours } \\
\text { than before MI. } \\
\text { Facilitating factors: financial stress, and male } \\
\text { gender. } \\
\text { Inhibiting factors: less social support, worse mental } \\
\text { health, work stress, worse physical health, and Drs' }\end{array}$ \\
\hline
\end{tabular}

This article is protected by copyright. All rights reserved 


\begin{tabular}{|c|c|c|c|c|c|}
\hline & & & & & advice. \\
\hline $\begin{array}{l}\text { Smedegaard et } \\
\text { al. (2017), } \\
\text { Denmark }\end{array}$ & $\begin{array}{l}\text { Quantitative, } \\
\text { nationwide, } \\
\text { retrospective, } \\
\text { cohort }\end{array}$ & $\begin{array}{l}\mathrm{N}=22,394, \text { Mean age: } \\
55 \text { years old (IQR: } 49- \\
\text { 59), Males: } 18,120 \\
\text { (80.9\%), Setting: Danish } \\
\text { National Register on } \\
\text { Public Transfer } \\
\text { Payments }\end{array}$ & $\begin{array}{l}\text { Age, gender, living } \\
\text { alone, baseline } \\
\text { income, education } \\
\text { level, HF, } \\
\text { arrhythmia, DM, } \\
\text { CVA, CKD, COPD, } \\
\text { depression, stress, } \\
\text { coronary } \\
\text { angiography, PPCI, } \\
\text { CABG, period of } \\
\text { hospitalisation }\end{array}$ & $\begin{array}{l}12 \text { months post } \\
\text { admission }\end{array}$ & $\begin{array}{l}\mathbf{4 1 . 7 \%} \text { vs. } 86.4 \% \text { vs. } 91.1 \% \mathrm{RTW} \text { at one month after } \\
\mathrm{MI} \text {, three months after } \mathrm{MI} \text { and after one year of } \mathrm{MI} \\
\text { respectively. } \\
\text { Inhibiting factors: female gender, HF, arrhythmia, } \\
\mathrm{DM}, \mathrm{CVA} \text {, and CKD. } \\
\text { Facilitating factors: male gender, higher education, } \\
\text { and higher salary. }\end{array}$ \\
\hline $\begin{array}{l}\text { Stendardo et } \\
\text { al. (2018), Italy }\end{array}$ & $\begin{array}{l}\text { Quantitative, } \\
\text { prospective }\end{array}$ & $\begin{array}{l}\mathrm{N}=102 \text {, Median age: } \\
56 \text { years old (IQR: } 50- \\
60) \text {, Males: } 90 \\
\text { (88.24\%), Setting: The } \\
\text { University Hospital of } \\
\text { Ferrara }\end{array}$ & $\begin{array}{l}\text { High school, } \\
\text { university degree, } \\
\text { METs physical } \\
\text { performance, self- } \\
\text { employed, HADS-D } \\
\text { score }\end{array}$ & $\begin{array}{l}12 \text { months post- } \\
\mathrm{MI}\end{array}$ & $\begin{array}{l}21.5 \% \text { vs. } 59.2 \% \text { vs. } 92.7 \% \text { RTW at one month } \\
\text { follow-up, two months follow-up, and after one year MI } \\
\text { respectively. } \\
\text { The median days of RTW post-MI: } 44 \text { days (IQR: } \\
\text { 33-88). } \\
\text { Facilitating factors: higher education ( } p=0.026 \text { ), self- } \\
\text { employed business ( } p<0.001 \text { ), white-collar ( } p=0.02 \text { ), } \\
\text { lower HADS-D scores ( } p=0.008 \text { ) and lower HADS-A } \\
\text { scores ( } p=0.009 \text { ). } \\
\text { Facilitating factors in MVA: higher education, self- } \\
\text { employed business, and lower HADS-D score. }\end{array}$ \\
\hline $\begin{array}{l}\text { Tella et al. } \\
\text { (2017), Spain }\end{array}$ & $\begin{array}{l}\text { Quantitative, } \\
\text { observational, } \\
\text { retrospective, }\end{array}$ & $\begin{array}{l}\mathrm{N}=497, \text { Diagnosed as } \\
\mathrm{MI}=295, \text { Mean age: } 53 \\
\text { years old (SD: } 7.4 \text { ), }\end{array}$ & $\begin{array}{l}\text { Age, gender, } \\
\text { diagnosis, meds } \\
\text { taken within one }\end{array}$ & $\begin{array}{l}\text { Follow-up until } \\
\text { the first RTW, } \\
\text { death, or the }\end{array}$ & $\begin{array}{l}\text { The estimated mean days of RTW post-MI: } 192 \\
\text { days }(p=0.002) \text {. }\end{array}$ \\
\hline
\end{tabular}

This article is protected by copyright. All rights reserved 


\begin{tabular}{|c|c|c|c|c|c|}
\hline & longitudinal & $\begin{array}{l}\text { Males: } 491(90.7 \%) \text {, } \\
\text { Setting: the primary care } \\
\text { clinical records of the } \\
\text { Lleida health region }\end{array}$ & year post-MI & $\begin{array}{l}\text { end of the study } \\
31 / 12 / 2012\end{array}$ & \\
\hline $\begin{array}{l}\text { Wang et al. } \\
\text { (2019), } \\
\text { Sweden }\end{array}$ & $\begin{array}{l}\text { Quantitative, } \\
\text { observational, } \\
\text { longitudinal, } \\
\text { Prospective, } \\
\text { cohort }\end{array}$ & $\begin{array}{l}\mathrm{N}=8,199, \text { Males: } 6,658 \\
\text { (81.2\%), Setting: the } \\
\text { Micro-data for analyses } \\
\text { of social insurance } \\
\text { (MiDAS) register }\end{array}$ & $\begin{array}{l}\text { Age, gender, } \\
\text { education level, } \\
\text { country of birth, } \\
\text { type of living area, } \\
\text { family situation, } \\
\text { previous SA and } \\
\text { unemployment, in- } \\
\text { and specialised } \\
\text { outpatient care due } \\
\text { to CMDs and other } \\
\text { mental disorders, } \\
\text { antidepressants, } \\
\text { anxiolytics, } \\
\text { sedatives, type of } \\
\text { infarction, MSDs, } \\
\text { DM, renal } \\
\text { insufficiency, } \\
\text { hypertension, } \\
\text { stroke, cancer and } \\
\text { other somatic } \\
\text { disorders }\end{array}$ & 3 years post-MI & $\begin{array}{l}\text { Inhibiting factors: female gender, lower education, } \\
\text { previous SA, previous unemployment (>180 days), } \\
\text { MSDs, hypertension, cancer, other somatic disorders, } \\
\text { CMDs, antidepressants, sedatives, anxiolytics, and } \\
\text { CABG. } \\
\text { Inhibiting factors in MVA: female gender, lower } \\
\text { education, previous SA, previous unemployment } \\
\text { (>180 days), STEMI, MSDs, hypertension, cancer, } \\
\text { other somatic disorders, CMDs, antidepressants, } \\
\text { sedatives, anxiolytics, and CABG. }\end{array}$ \\
\hline Warraich et al. & Quantitative, & $\mathrm{N}=9,319$, Mean age: & Age, gender, race, & 6 weeks, and 6 , & $10 \%$ had a worse employment condition at one year \\
\hline
\end{tabular}

This article is protected by copyright. All rights reserved 


\begin{tabular}{|c|c|c|c|c|c|}
\hline (2018), USA & $\begin{array}{l}\text { observational, } \\
\text { longitudinal, }\end{array}$ & $\begin{array}{l}55.8 \text { years old (SD: } 9.2) \text {, } \\
\text { Males: } 6780(72.7 \%) \text {, } \\
\text { Setting: } 2333 \text { hospitals } \\
\text { in USA }\end{array}$ & $\begin{array}{l}\text { BMI, STEMI, prior } \\
\text { MI, DM, } \\
\text { hypertension, } \\
\text { smoker, number of } \\
\text { unplanned } \\
\text { rehospitalisation } \\
\text { within one year } \\
\text { post discharge, } \\
\text { post discharge } \\
\text { bleeding, within } \\
\text { one year, meds } \\
\text { taken within year } \\
\text { post discharge, } \\
\text { baseline EQ5D } \\
\text { VAS, and baseline } \\
\text { PHQ2 }\end{array}$ & $\begin{array}{l}12 \text { and } 15 \\
\text { months post } \\
\text { discharge }\end{array}$ & $\begin{array}{l}\text { post discharge: } 7 \% \text { no longer worked; and } 3 \% \text { worked } \\
\text { less. } \\
\text { Inhibiting factors: female gender ( } p=0.002) \text {, smoking } \\
\text { ( } p=0.025) \text {, DM ( } p=0.012) \text {, hypertension }(p=0.0003) \text {, } \\
\text { no drug-eluting stent }(p=0.01) \text {, recurrent } \mathrm{MI}(p<0.001) \text {, } \\
\text { revascularisation ( } p<0.001) \text {, stroke }(p=0.039) \text {, } \\
\text { development of post-discharge bleeding }(p<0.001) \text {, } \\
\text { readmissions ( } p<0.001) \text {, PHQ2 score }>3 \quad(p<0.042) \text {, } \\
\text { and lower EQ5D VAS ( } p<0.013) \text {. } \\
\text { Inhibiting factors in MVA: readmissions }(p=0.0003) \text {, } \\
\text { smoking ( } p=0.0215) \text {, hypertension }(p=0.0076) \text {, and } \\
\text { development of post-discharge bleeding }(p=0.0022) \text {. }\end{array}$ \\
\hline
\end{tabular}

This article is protected by copyright. All rights reserved 
Abbreviations: ACS: acute coronary syndrome; AF: atrial fibrillation; ANOVA: analysis of covariance; BDI-II: Beck Depression Inventory-II; BMI: body mass index; CABG: coronary artery bypass grafting; CAD: coronary artery disease; CHD: coronary heart disease; CKD: chronic kidney disease; CMD: common mental disorder; COPD: chronic obstructive pulmonary disease; CR: cardiac rehabilitation; CVA: cerebrovascular disease; DASI: Duke Activity Status Index; Dept: department; DM: diabetes mellitus; Dr: doctor; EQ5D: EuroQoL-5 Dimensions; GHQ: General Health Questionnaire; HADS-A: anxiety subscale of the Hospital Anxiety and Depression Scale; HADS-D: depression subscale of the Hospital Anxiety and Depression Scale; HCSD: health care system delay; HF: heart failure; IHD: ischaemic heart disease; IQR: interquartile range; LVEF: left ventricular ejection fraction; Meds: medications; MET: metabolic equivalent; MI: myocardial infarction; Mins: minutes; MSD: musculoskeletal disorder; MVA: multivariable analysis; N/A: not applicable; NHP: Nottingham Health Profile; NRTW: not return to work; PCS: physical component score; PHQ: Patient Health Questionnaire; PPCl: primary percutaneous coronary intervention; Pts: patients; QoL: quality of life; RTW: return to work; SA: sickness absence; SD: standard deviation; SF-12: Short-form 12; SHCQ: Somatic Health Complaints Questionnaire; STEMI: ST-elevation myocardial infarction; T2DM: type 2 diabetes mellitus; TIMI: thrombolysis in myocardial infarction; UK: United Kingdom; USA: United States of America; VAS: visual analog scale.

This article is protected by copyright. All rights reserved 
Table 4 Summary of factors that were related to patients' RTW post-MI

\section{Individual factors}

\section{Sociodemographic factors:}

Age: Attarchi et al. 2012; Brink et al. 2008; de Jonge, Zuidersma \& Bültmann 2014; Isaaz et al. 2010; Jiang et al. 2018; Laut et al. 2014; Waszkowska \& Szymczak 2009.

Gender: Dreyer et al. 2016; Duijts et al. 2017; Isaaz et al. 2010; Jiang et al. 2018; Laut et al. 2014; Şahan et al. 2016; Smedegaard et al. 2017; Wang et al. 2019; Warraich et al. 2018.

Educational level: de Jonge, Zuidersma \& Bültmann 2014; Dreyer et al. 2016; Jiang et al. 2018; Smedegaard et al. 2017; Stendardo et al. 2018; Wang et al. 2019; Waszkowska \& Szymczak 2009.

Marriage status: Dreyer et al. 2016; Isaaz et al. 2010.

Life insurance: Dreyer et al. 2016.

Financial stress: Dreyer et al. 2016; Şahan et al. 2016.

Social support / isolation: Dreyer et al. 2016; Şahan et al. 2016; Waszkowska \& Szymczak 2009.

\section{Behavioural factors:}

Smoking: Attarchi et al. 2012; Dreyer et al. 2016; Jiang et al. 2018; Warraich et al. 2018.

Daily footsteps: Brink et al. 2008.

\section{Disease and health-related factors:}

ST-elevation myocardial infarction: Wang et al. 2019.

Location of myocardial infarction: de Jonge, Zuidersma \& Bültmann 2014; Isaaz et al. 2010; Jiang et al. 2018.

The time of chest pain onset: Isaaz et al. 2010.

Diabetes mellitus: Attarchi et al. 2012; Dreyer et al. 2016; Jiang et al. 2018; Smedegaard et al. 2017; Warraich et al. 2018.

Hypertension: Attarchi et al. 2012; Dreyer et al. 2016; Jiang et al. 2018; Wang et al. 2019; Warraich et al. 2018.

Hyperlipoproteinemia: Babić et al. 2015.

Number of risk factors: Dreyer et al. 2016; Isaaz et al. 2010.

Ischaemic heart disease / coronary artery disease: Attarchi et al. 2012; Dreyer et al. 2016.

Arrhythmia: Smedegaard et al. 2017.

Chronic kidney disease: Smedegaard et al. 2017.

Cerebrovascular disease: Smedegaard et al. 2017.

Musculoskeletal disorders: Wang et al. 2019.

Cancer: Wang et al. 2019

Heart failure: Smedegaard et al. 2017; de Jonge, Zuidersma \& Bültmann 2014.

Left ventricular ejection fraction: Attarchi et al. 2012; de Jonge, Zuidersma \& Bültmann 2014; Dreyer et al. 2016; Isaaz et al. 2010; Mirmohammadi et al. 2014.

Angina: Attarchi et al. 2012; Jiang et al. 2018. 
Infection: Jiang et al. 2018.

Atrial fibrillation: Jiang et al. 2018.

Recurrent myocardial infarction: Warraich et al. 2018.

Post-discharge bleeding: Warraich et al. 2018.

Stroke: Jiang et al. 2018; Warraich et al. 2018.

Readmissions: Warraich et al. 2018.

General health: Brink et al. 2008; Duijts et al. 2017; Waszkowska \& Szymczak 2009.

Physical health: Brink et al. 2008; Dreyer et al. 2016; Şahan et al. 2016.

Bodily pain: Brink et al. 2008; Waszkowska \& Szymczak 2009.

Fatigue / energy: Brink et al. 2008; Waszkowska \& Szymczak 2009.

Mobility: Waszkowska \& Szymczak 2009.

Depression: de Jonge, Zuidersma \& Bültmann 2014; Dreyer et al. 2016; Stendardo et al. 2018; Warraich et al. 2018; Wang et al. 2019; Waszkowska \& Szymczak 2009.

Anxiety: Stendardo et al. 2018; Wang et al. 2019; Waszkowska \& Szymczak 2009.

Stress: Dreyer et al. 2016.

Patients' own decision: Jiang et al. 2018; Mirmohammadi et al. 2014.

\section{Healthcare factors}

Duration of hospitalisation: Attarchi et al. 2012; Dreyer et al. 2016; Isaaz et al. 2010; Jiang et al. 2018.

Time to call ambulance after chest pain: Isaaz et al. 2010.

Expectation of being at work: Duijts et al. 2017.

Health care system delay: Laut et al. 2014.

Coronary artery bypass graft: Attarchi et al. 2012; Wang et al. 2019.

Drug-eluting stent: Warraich et al. 2018.

Thrombolysis in myocardial infarction flow grade 3: Isaaz et al. 2010.

Revascularisation: Warraich et al. 2018.

Cardiac rehabilitation: Dreyer et al. 2016; Isaaz et al. 2010.

Doctor's advice: Mirmohammadi et al. 2014; Şahan et al. 2016.

\section{Work-related factors}

Work classification: Attarchi et al. 2012; Babić et al. 2015; de Jonge, Zuidersma \& Bültmann 2014; Dreyer et al. 2016; Isaaz et al. 2010; Jiang et al. 2018; Stendardo et al. 2018.

Work energy requirement: Attarchi et al. 2012; de Jonge, Zuidersma \& Bültmann 2014; Waszkowska \& Szymczak 2009.

Salary: Babić et al. 2015; Jiang et al. 2018; Smedegaard et al. 2017.

Job stress / satisfaction: Şahan et al. 2016; Mirmohammadi et al. 2014.

Work change: Dreyer et al. 2016.

Work hours: Dreyer et al. 2016.

Being fired: Babić et al. 2015; Dreyer et al. 2016; Mirmohammadi et al. 2014; Warraich et al.'s 2018.

This article is protected by copyright. All rights reserved 
Previous sickness absence: Wang et al. 2019.

Previous unemployment: Wang et al. 2019.

Abbreviations: MI: myocardial infarction; RTW: return to work.

This article is protected by copyright. All rights reserved 
Records identified:

MEDLINE $(n=2,286)$,

CINAHL $(n=922)$,

Academic Search Complete $(n=2,436)$,

EMBASE $(n=5,312)$,

SCOPUS $(n=4,328)$,

ProQuest Health and Medicine (searching by title:

$$
\mathrm{n}=1,562) \text {, }
$$

ProQuest Health and Medicine (searching by abstract: $n=5,371$ )

$(n=22,217)$

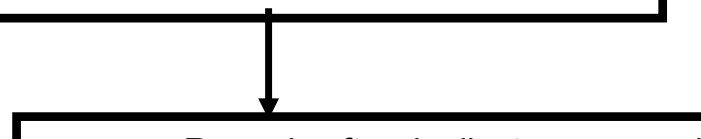

Additional records identified using Google

$(n=1)$

Records after duplicates removed

$(n=15,133)$
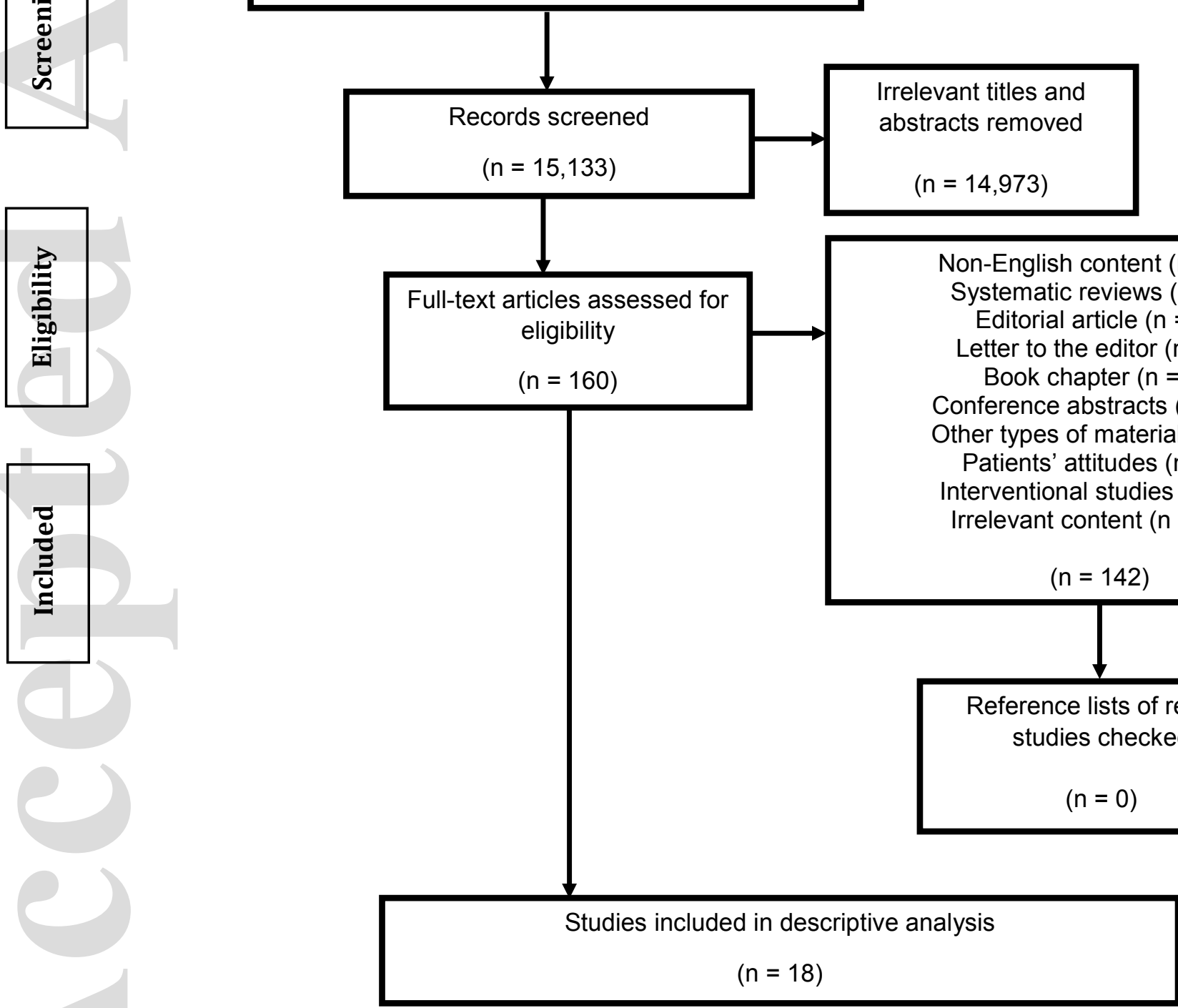

Figure 1 The process of study selection

This article is protected by copyright. All rights reserved 


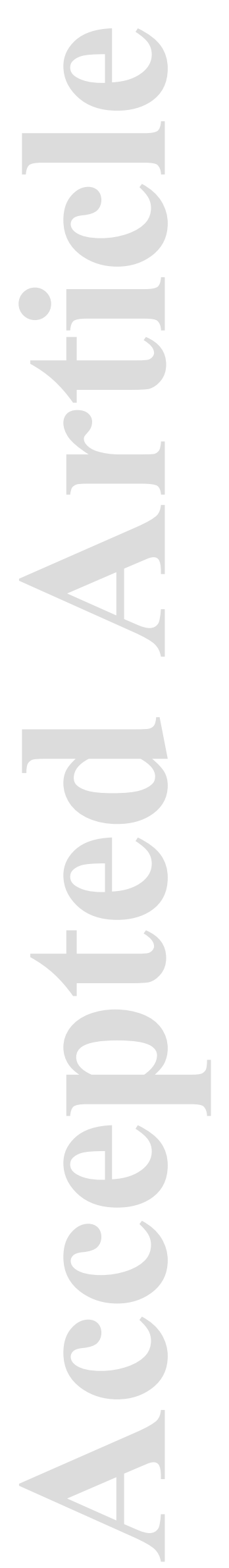

This article is protected by copyright. All rights reserved 